Supporting Information for

\title{
Highly Dispersed Platinum Chlorine Atoms Anchored on Gold Quantum Dots for Highly Efficient Electrocatalyst
}

Lan Hui, ${ }^{\dagger, *}$ Xueting Zhang, ${ }^{\dagger, *}$ Yurui Xue, ${ }^{\dagger}$ Xi Chen, ${ }^{\dagger, *}$ Yan Fang, ${ }^{\dagger, *}$ Chengyu Xing, ${ }^{\dagger}$ Yuxin Liu, ${ }^{\dagger, \star}$ Xuchen Zheng, ${ }^{\dagger, *}$ Yuncheng Du, ${ }^{\dagger}$ Chao Zhang, ${ }^{\dagger, *}$ Feng He,,,$++\downarrow$ Yuliang $\mathrm{Li}^{*}, \dagger, \dagger$

†Institute of Chemistry, Chinese Academy of Sciences, Beijing 100190, PR China.

University of Chinese Academy of Sciences, Beijing 100049, PR China.

\section{Contents}

Experimental Methods

Materials

Preparation of $\mathrm{PtCl}_{2} \mathrm{Au}(111) / \mathrm{GDY}$

Characterization

Electrochemical measurements

XAFS measurements

XAFS analysis and results

Computational details

Supplementary Figures

Supplementary Tables

References 


\section{Experimental Methods}

Materials. Dihydrogen hexachloroplatinate $\left(\mathrm{H}_{2} \mathrm{PtCl}_{6} \cdot 6 \mathrm{H}_{2} \mathrm{O}, 99.9 \%\right)$, hydrogen tetrachoroaurate $\left(\mathrm{HAuCl}_{4} \cdot 3 \mathrm{H}_{2} \mathrm{O}, 99.9 \%\right)$ and commercial $20 \% \mathrm{Pt} / \mathrm{C}$ were purchased from Alfa Aesar. Methanaol $\left(\mathrm{CH}_{3} \mathrm{OH}, 99.9 \%\right)$ were purchased from Acros Organics. $\mathrm{KOH}(95 \%)$ was purchased from Energy Chemical. All the reagents and solvents were used as received and without further purification.

\section{Preparation of $\mathrm{PtCl}_{2} \mathrm{Au}(111) / \mathrm{GDY}$.}

GDY was prepared according to the previously reported method. ${ }^{1}$ The as-prepared GDY was immersed in $\mathrm{H}_{2} \mathrm{SO}_{4}(50 \mathrm{~mL})$ solution containing $\mathrm{H}_{2} \mathrm{PtCl}_{6} \cdot 6 \mathrm{H}_{2} \mathrm{O}(25 \mathrm{mg})$ for 2 hours to allow the adsorption of Pt species. Subsequently, these samples were immersed in $\mathrm{HAuCl}_{4} \cdot 3 \mathrm{H}_{2} \mathrm{O}$ solution for epaxial growth of $\mathrm{Au}$ QDs by the electrodeposition method at $5 \mathrm{~mA} \mathrm{~cm}^{-2}$ for $20 \mathrm{~s}$. Various samples were prepared under different electrodeposition orders ( $\mathrm{Pt}$ to $\mathrm{Au}$, or $\mathrm{Au}$ to $\mathrm{Pt}$ ) and different electrodeposition times $(5 \mathrm{~s}, 10 \mathrm{~s}, 15 \mathrm{~s}, 20 \mathrm{~s}, 25 \mathrm{~s}$ and $30 \mathrm{~s})$. The obtained samples were thoroughly cleaned and immediately used for electrochemical measurements.

\section{Characterization.}

The morphologies of the samples were characterized by TEM (JEM-2100F). The Xray photoelectron spectroscopy (XPS, Thermo Scientific ESCALab 250Xi), XRD (Rigaku, Japan) and Raman spectroscopy (Renishaw-2000) were used to obtain the structural information of samples. HAADF-STEM images were carried out by an aberration-corrected cubed FET Titan Cubed Themis G2300 or JEM-ARM200F.

\section{Electrochemical measurements.}

$\mathrm{CV}$ curves were recorded using a typical three-electrode setup on a $\mathrm{CHI} 660 \mathrm{E}$ workstation. A graphite rod was used as the counter electrode, saturated calomel electrode (SCE) was used as the reference electrode, and the as-prepared samples were used as the working electrode. The electrolytes contain $1.0 \mathrm{M} \mathrm{KOH}$ and $1.0 \mathrm{M} \mathrm{CH}_{3} \mathrm{OH}$ (or $\mathrm{CH}_{3} \mathrm{CH}_{2} \mathrm{OH}$ ) solution, the electrocatalytic performances were tested through the $\mathrm{CV}$ 
curve method at $50 \mathrm{mV} \mathrm{s}^{-1}$. For $\mathrm{CO}$ stripping measurements, $\mathrm{CO}$ was adsorbed on the electrocatalyst by bubbling $\mathrm{CO}$ in $1 \mathrm{M} \mathrm{KOH}$ for $30 \mathrm{~min}$ and was held at $-0.96 \mathrm{~V}$ vs SCE. Stripping tests were tested from -0.98 to $0 \mathrm{~V}$ for three consecutive scans in the solution, in which the $\mathrm{CO}$ was removed by bubbling the electrolyte with $\mathrm{N}_{2}$ for $25 \mathrm{~min}$.

\section{XAFS measurements.}

The X-ray absorption find structure spectra (Fe K-edge) were collected at 1W1B station in Beijing Synchrotron Radiation Facility (BSRF). The storage rings of BSRF were operated at $2.5 \mathrm{GeV}$ with an average current of $250 \mathrm{~mA}$. Using $\mathrm{Si}(111)$ doublecrystal monochromator, the data collection were carried out in transmission/fluorescence mode using ionization chamber. All spectra were collected in ambient conditions.

\section{XAFS analysis and results.}

The acquired EXAFS data were processed according to the standard procedures using the ATHENA module implemented in the IFEFFIT software packages. The $k^{3}-$ weighted EXAFS spectra were obtained by subtracting the post-edge background from the overall absorption and then normalizing with respect to the edge-jump step. Subsequently, $k^{3}$-weighted $\chi(\mathrm{k})$ data of Fe K-edge were Fourier transformed to real $(\mathrm{R})$ space using a hanning windows $\left(\mathrm{dk}=1.0 \AA^{-1}\right)$ to separate the EXAFS contributions from different coordination shells $\mathrm{s}^{2-4}$. To obtain the quantitative structural parameters around central atoms, least-squares curve parameter fitting was performed using the ARTEMIS module of IFEFFIT software packages.

\section{Computational details.}

All the density functional theory (DFT) calculations were carried out using the Vienna $\mathrm{Ab}$ initio Simulations Package (VASP). ${ }^{5-8}$ The GGA-PBE exchange-correlation functional was used, ${ }^{9}, 10$ and the interactions between ion cores and valence electrons were described following the projector augmented wave (PAW) approach. ${ }^{11}$ The oneelectron wavefunction was developed using a plane-wave basis set with a cutoff energy of $450 \mathrm{eV}$. Reciprocal space was sampled using Monkhorst-Pack mesh k-space 
sampling grids ${ }^{12}$ with $3 \times 3 \times 1$ k-point grids for all the models. For the convergence study of density of states (DOS), the much dense $5 \times 5 \times 1 \mathrm{k}$-point grids were set. The $\mathrm{PtCl}_{2} \mathrm{Au}(111) / \mathrm{GDY}$ model was built using primitive cell of graphdiyne (GDY) with single layer (18 C atoms) and $3 \times 3$ supercell of $\mathrm{Au}(111)$ with three layers (27 $\mathrm{Au}$ atoms) as substrate. The $\mathrm{PtCl}_{2}$ site was then adsorbed on the $\mathrm{Au}(111) / \mathrm{GDY}$ surface. All the structures in this work were fully relaxed until the forces on each of the atoms were less than $0.02 \mathrm{eV} / \AA$, and the self-consistency convergence criterion of energy is below $10^{-6}$ $\mathrm{eV}$. To avoid the periodic interaction in the systems, a vacuum space of $20 \AA$ was set in the direction normal to the surface.

The free energy change $(\Delta \mathrm{G})$ was calculated ${ }^{13}$ using the computational hydrogen electrode model:

$\Delta \mathrm{G}=\Delta \mathrm{E}+\Delta \mathrm{E}_{\mathrm{ZPE}}-\mathrm{T} \Delta \mathrm{S}+\Delta \mathrm{G}_{\mathrm{U}}$

where $\Delta \mathrm{E}$ is the total energy change obtained from DFT calculations, $\Delta \mathrm{E}_{\mathrm{ZPE}}$ is the change in zero-point energy, $\mathrm{T}$ is room temperature $(298.15 \mathrm{~K})$, and the $\Delta \mathrm{S}$ is the change in entropy. $\Delta \mathrm{G}_{\mathrm{U}}$ is the free energy correction term for the electrode potential, which can be obtained by: $\Delta \mathrm{G}_{\mathrm{U}}=-\mathrm{eU}$, where $\mathrm{U}$ refers to the electrode potential with respect to standard hydrogen electrode, and e is the transferred charge. ${ }^{14,15}$ The free energy change of $\mathrm{H}^{+}$in solution is estimated by $1 / 2 \Delta \mathrm{G}\left(\mathrm{H}_{2}\right)$. The entropy of the $\mathrm{H}_{2}$ is taken from the NIST database, while the entropies of the intermediates during MOR were calculated from the vibrational frequencies.

ZPE values could be derived after frequency calculation ${ }^{16}$ by:

$Z P E=\frac{1}{2} \sum h v_{i}$

TS values of adsorbed species were calculated after obtaining the vibrational frequencies ${ }^{17}$ :

$$
T S_{v}=k_{B} T\left[\sum_{K} \ln \left(\frac{1}{1-e^{-h v_{K} / \mathrm{k}_{B} T}}\right)+\sum_{K} \frac{h v_{K}}{k_{B} T} \frac{1}{\left(e^{h v_{K} / \mathrm{k}_{B} T}-1\right)}\right]
$$


Where $\mathrm{k}_{\mathrm{B}}$ is the Boltzmann constant, $\mathrm{T}$ is Temperature, $\mathrm{K}$ is vibrational mode, $\mathrm{v}$ is vibrational frequency for the intermediates, which is obtained from DFT calculations using VASP. 


\section{Supplementary Figures}

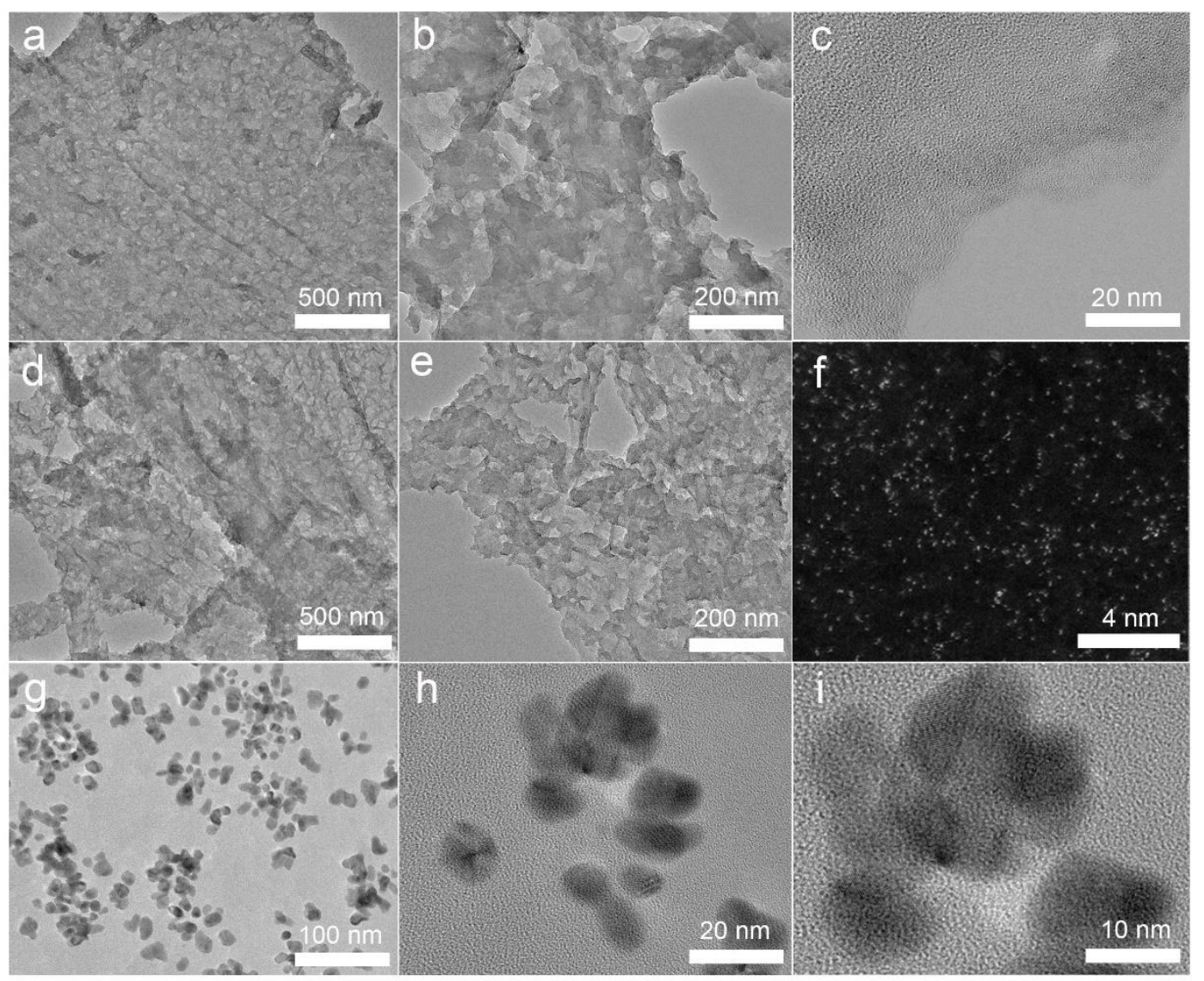

Figure S1. The TEM images of (a-c) GDY and (d, e) $\mathrm{PtCl}_{4} \mathrm{SS} / \mathrm{GDY}$. (f) The HAADF-

STEM images of $\mathrm{PtCl}_{4} \mathrm{SS} / \mathrm{GDY}$. (g-i) The TEM images of Au(111)/GDY. 


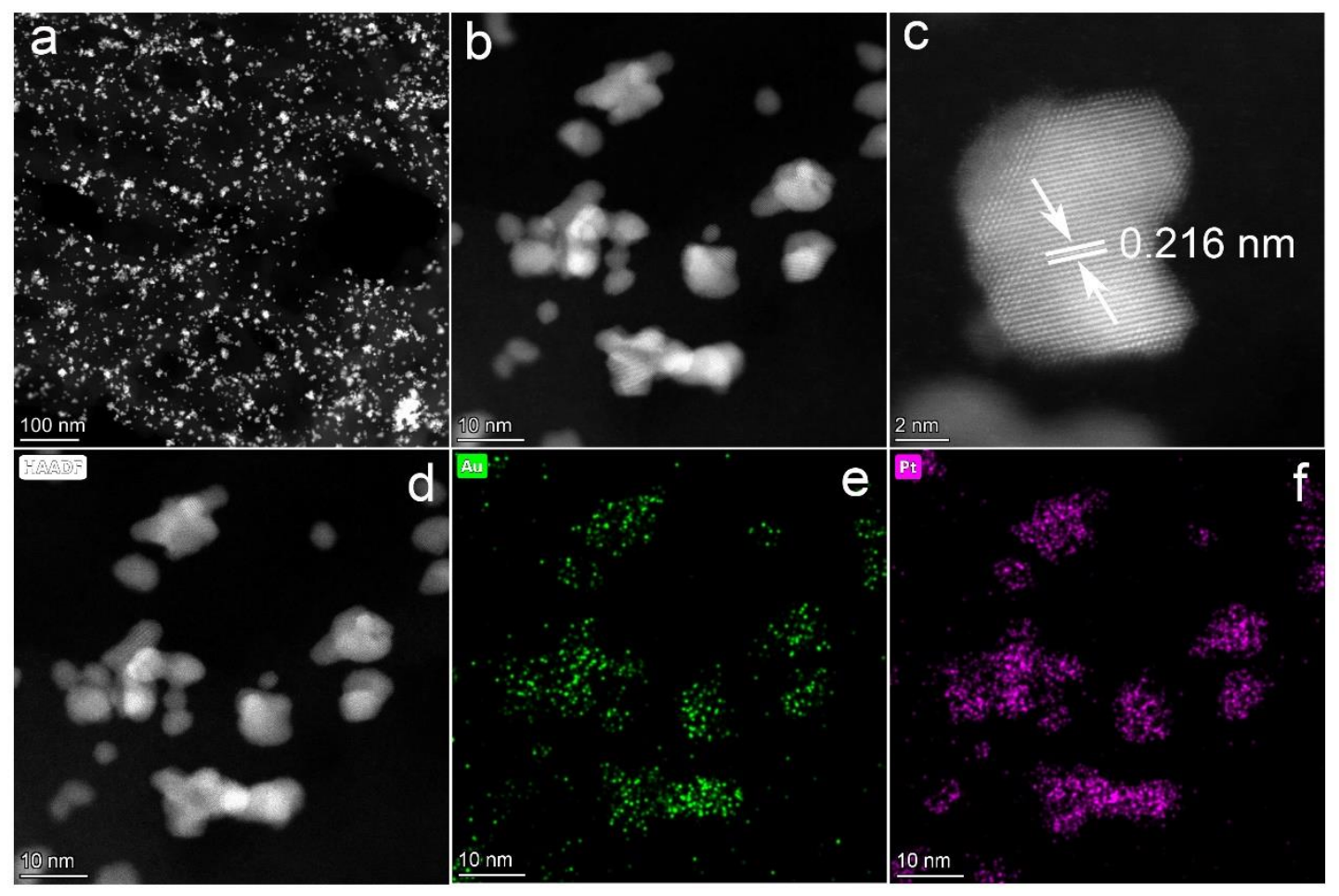

Figure S2 . (a-c) The HADDF-STEM images and (d-f) the corresponding EDS mapping images of AuPt/GDY. 

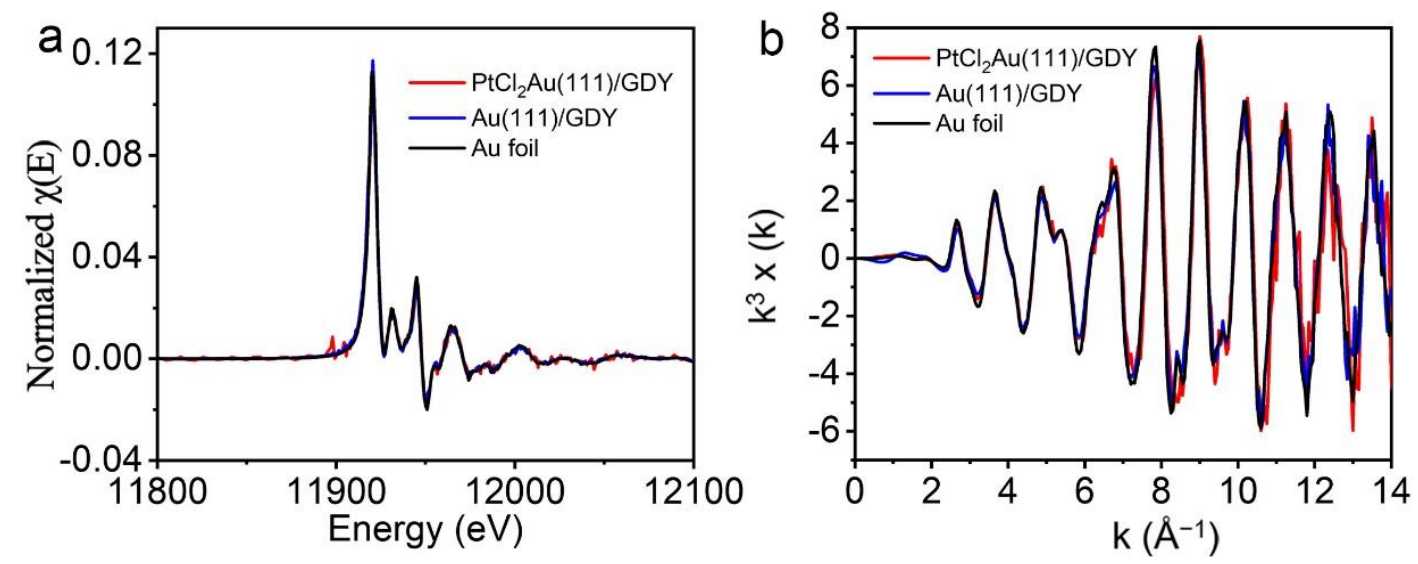

Figure S3. (a) The calculated first-derivative curves and (b) $k$ space fitting curves for $\mathrm{PtCl}_{2} \mathrm{Au}(111) / \mathrm{GDY}, \mathrm{Au}(111) / \mathrm{GDY}$, and Au foil. 

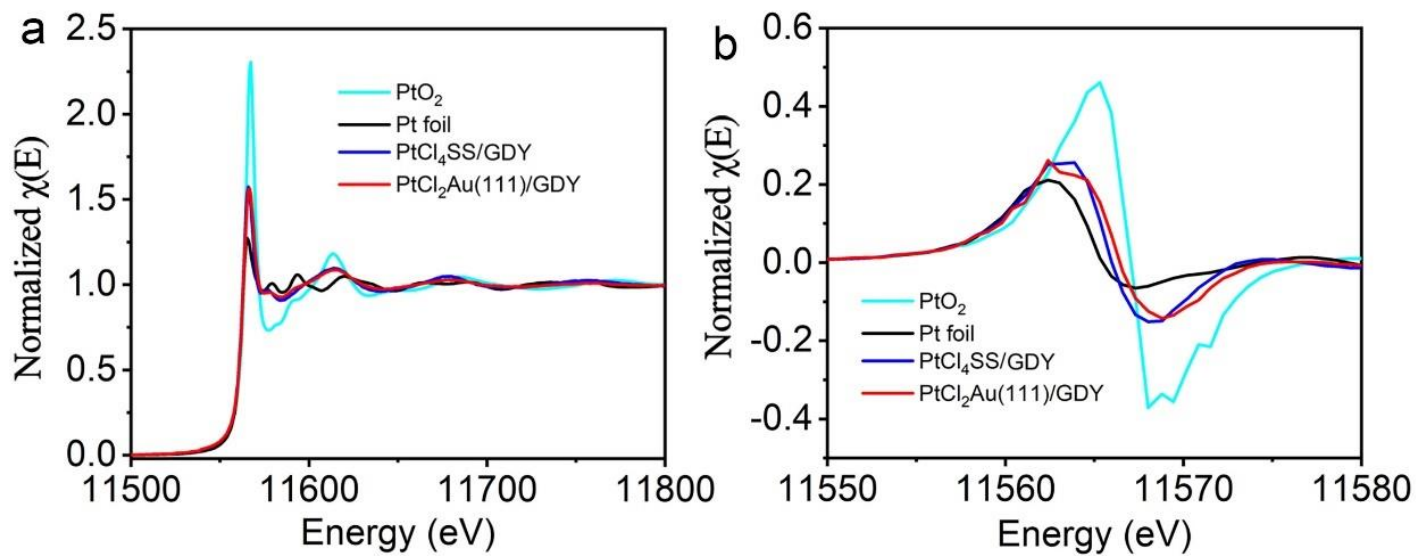

Figure S4. (a) The normalized Pt L3-edge XANES spectra and (b) calculated firstderivative curves for $\mathrm{PtCl}_{2} \mathrm{Au}(111) / \mathrm{GDY}, \mathrm{PtCl}_{4} \mathrm{SS} / \mathrm{GDY}, \mathrm{PtO}_{2}$ and $\mathrm{Pt}$ foil. 
a

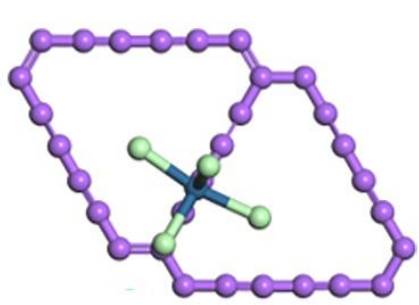

C

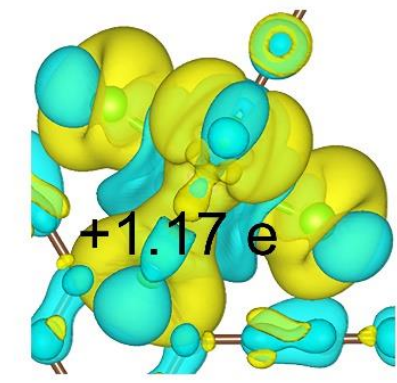

b

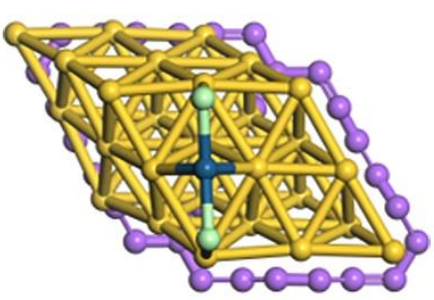

d

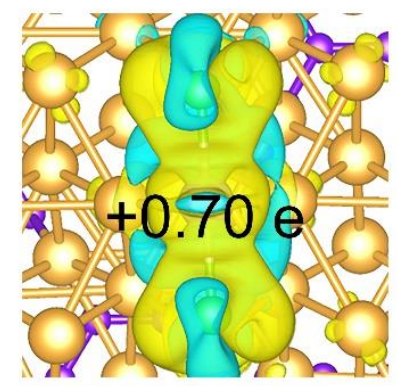

Figure S5. The calculation model for (a) $\mathrm{PtCl}_{4} \mathrm{SS} / \mathrm{GDY}$ and (b) $\mathrm{PtCl}_{2} \mathrm{Au}(111) / \mathrm{GDY}$. The different charge density distribution and the corresponding Bader charge of $\mathrm{Cl}$ atoms in (c) $\mathrm{PtCl}_{4} \mathrm{SS} / \mathrm{GDY}$ and (d) $\mathrm{PtCl}_{2} \mathrm{Au}(111) / \mathrm{GDY}$. (Yellow area represents electron accumulation, Bule area represents electron depletion. Isosurface $=0.001$ e/Bohr3).

Figure S5 shows the DFT calculation results of the electron gain/loss behavior of $\mathrm{Cl}$ element in $\mathrm{PtCl}_{2} \mathrm{Au}(111) / \mathrm{GDY}$ and $\mathrm{PtCl}_{4} \mathrm{SS} / \mathrm{GDY}$ samples. Differential charge density distribution show that the $\mathrm{Cl}$ atoms gain electron in two samples. Bader charge analysis further indicate there is a total of +0.70 electron gain in $\mathrm{PtCl}_{2} \mathrm{Au}(111) / \mathrm{GDY}$ (Figure $\mathrm{S} 5 \mathrm{~b}$ and S5d), while +1.17 electron gain in $\mathrm{PtCl}_{4} \mathrm{SS} / \mathrm{GDY}$ (Figure S5a and S5c). Hence, compared to $\mathrm{PtCl}_{4} \mathrm{SS} / \mathrm{GDY}$, the electrons of $\mathrm{Cl}$ element in $\mathrm{PtCl}_{2} \mathrm{Au}(111) / \mathrm{GDY}$ are less, in consistent with the XPS results. 


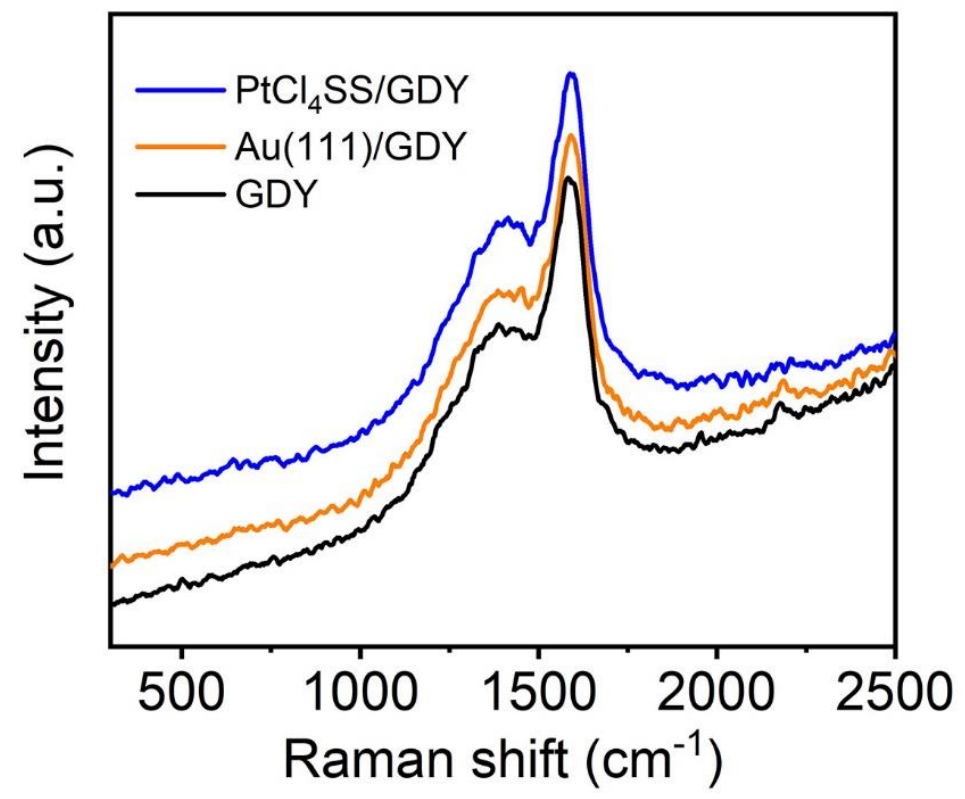

Figure S6. The Raman spectra of $\mathrm{PtCl}_{4} \mathrm{SS} / \mathrm{GDY}$ (blue line), $\mathrm{Au}(111) / \mathrm{GDY}$ (orange line) and GDY (black line). 


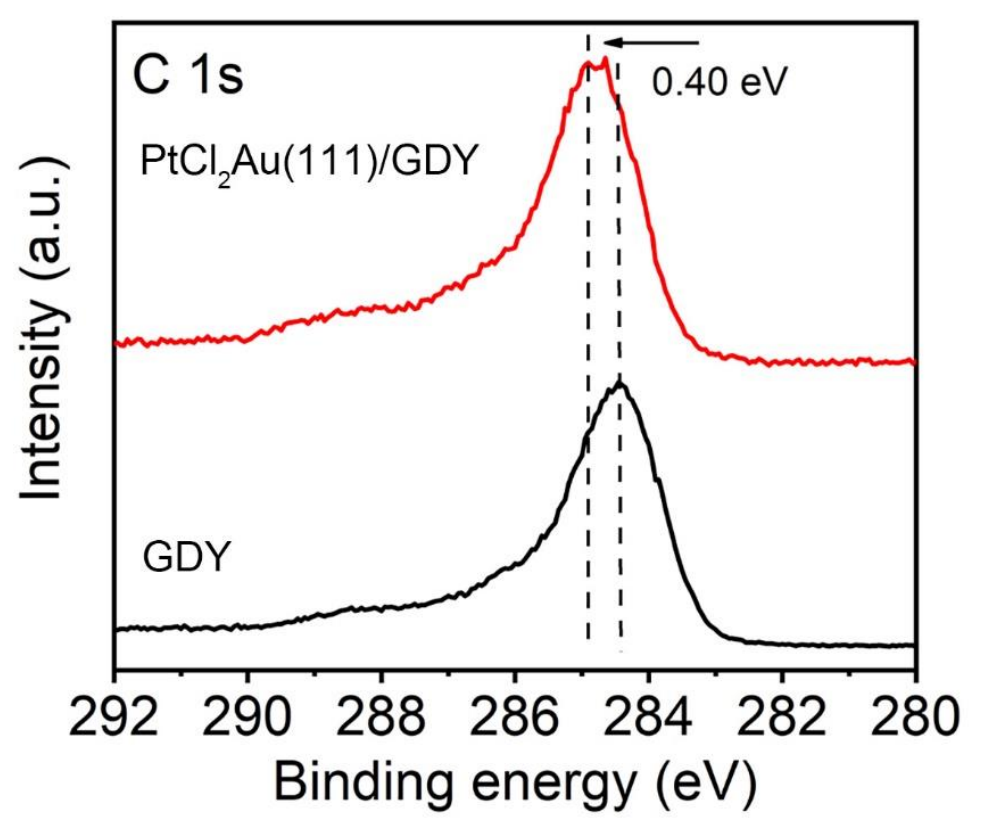

Figure S7. The C 1s XPS spectra of $\mathrm{PtCl}_{2} \mathrm{Au}(111) / \mathrm{GDY}$ (red line) and GDY (black line). 


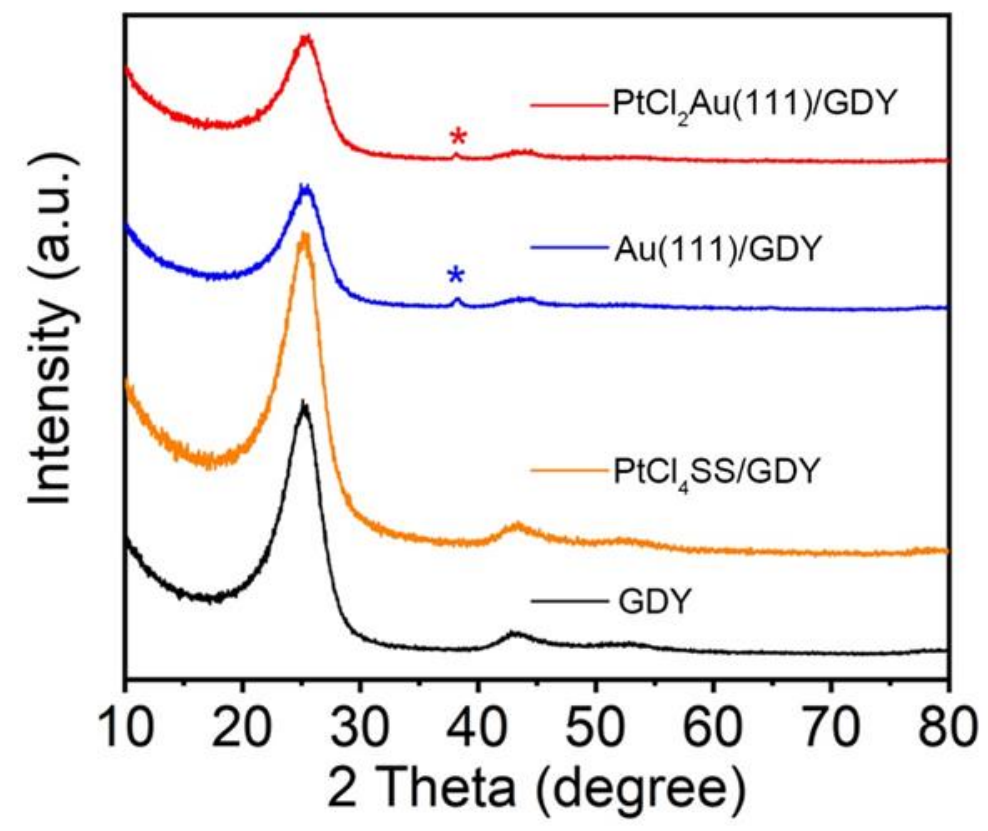

Figure S8. The XRD patterns of $\mathrm{PtCl}_{2} \mathrm{Au}(111) / \mathrm{GDY}$ (red line), $\mathrm{Au}(111) / \mathrm{GDY}$ (blue line), $\mathrm{PtCl}_{4} \mathrm{SS} / \mathrm{GDY}$ (orange line) and GDY (black line). 


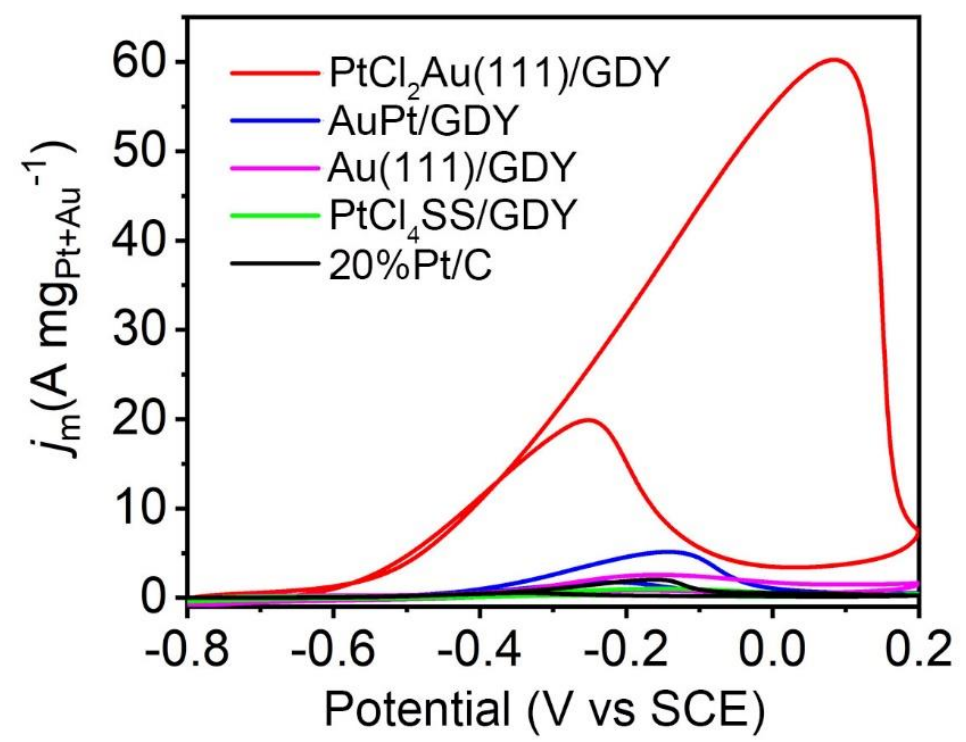

Figure S9. All metal $(\mathrm{Pt}+\mathrm{Au})$ mass-normalized $\mathrm{CV}$ curves of different samples for EOR. 


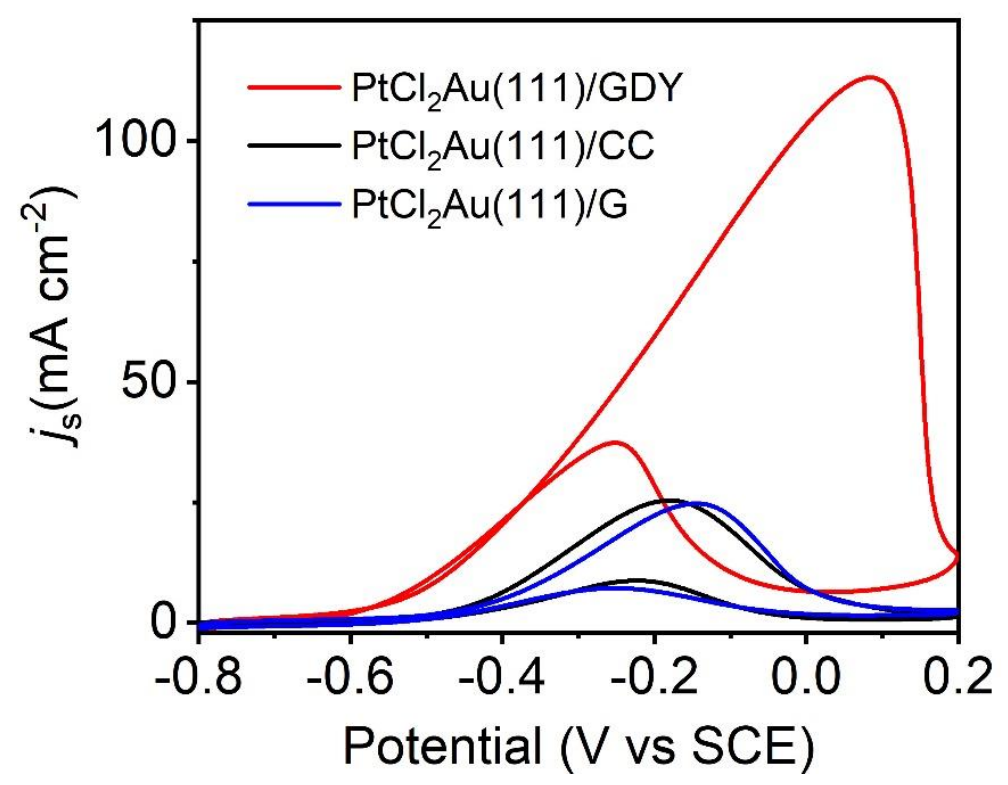

Figure S10. The $\mathrm{CV}$ curves of the $\mathrm{PtCl}_{2} \mathrm{Au}(111) / \mathrm{GDY}, \mathrm{PtCl}_{2} \mathrm{Au}(111) / \mathrm{CC}$ and $\mathrm{PtCl}_{2} \mathrm{Au}(111) / \mathrm{G}$ for MOR. 


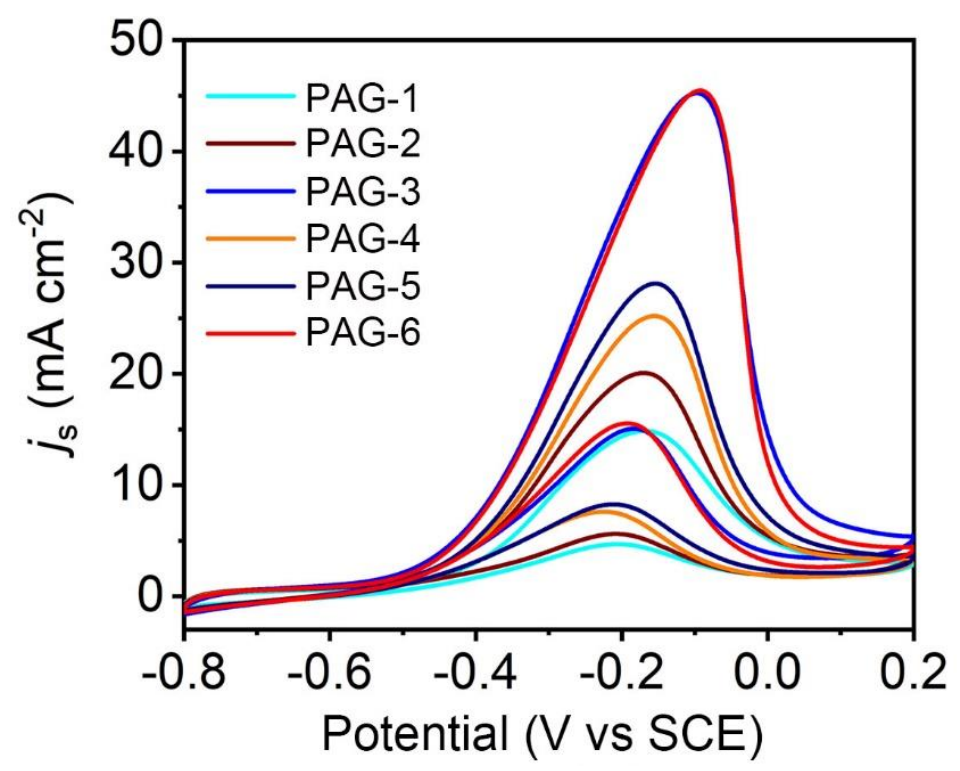

Figure S11. The specific activities of PAG-1 (5 s), PAG-2 (10 s), PAG-3 (15 s), PAG4 (25 s), PAG-5 (30 s) obtained by different electrodeposition time of the $\mathrm{PtCl}_{2} \mathrm{Au}(111) / \mathrm{CDY}(\mathrm{PAG})$. 


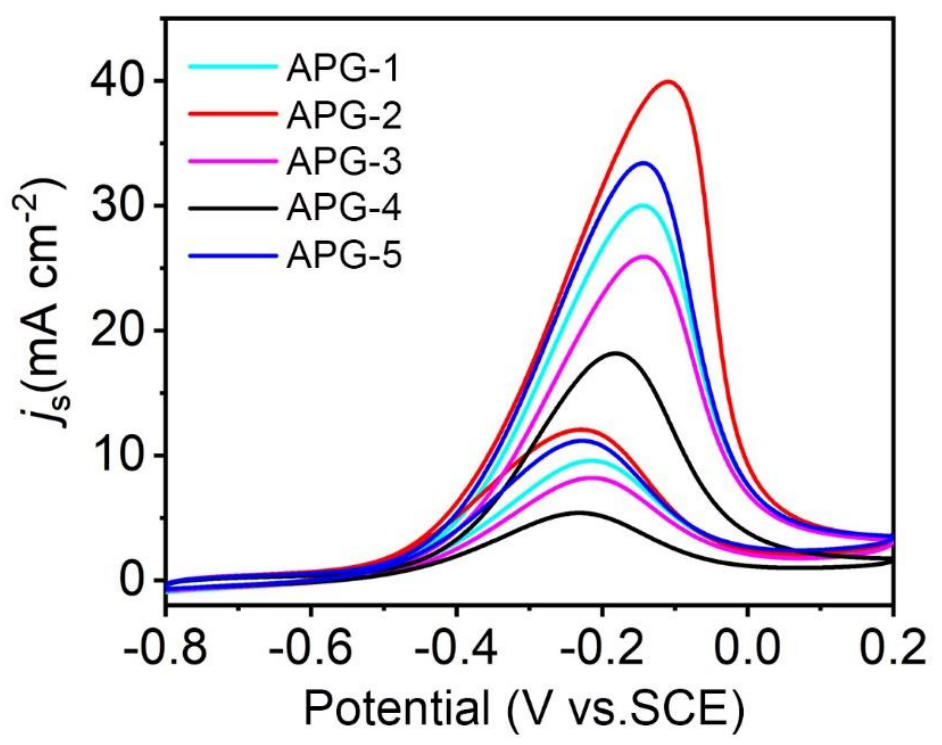

Figure S12. The specific activities of APG-1 (5 s), APG-2 (10 s), APG-3 (15 s), APG$4(20 \mathrm{~s})$ and APG-5 (25 s) obtained by different electrodeposition orders of the $\mathrm{Au}(111) \mathrm{PtCl}_{2} / \mathrm{CDY}$ (APG). 


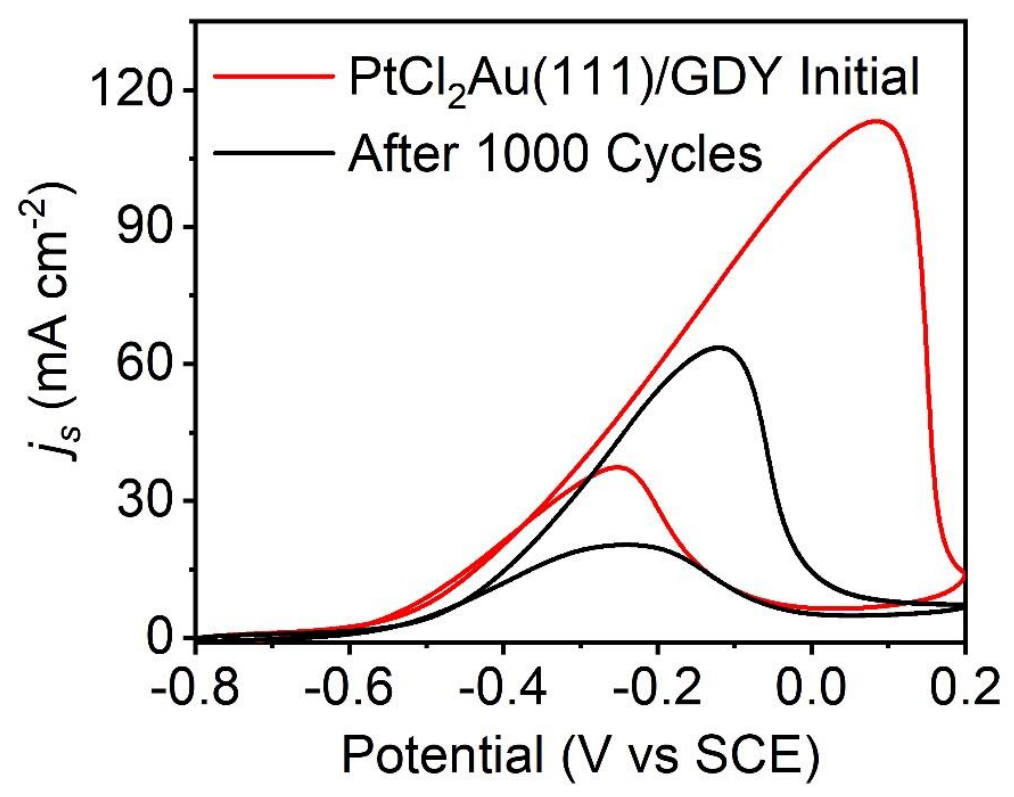

Figure S13. The CV curves of $\mathrm{PtCl}_{2} \mathrm{Au}(111) / \mathrm{GDY}$ obtained in $1.0 \mathrm{M} \mathrm{KOH}+1.0 \mathrm{M}$ $\mathrm{CH}_{3} \mathrm{OH}$ for MOR before and after 1000 cycles. 


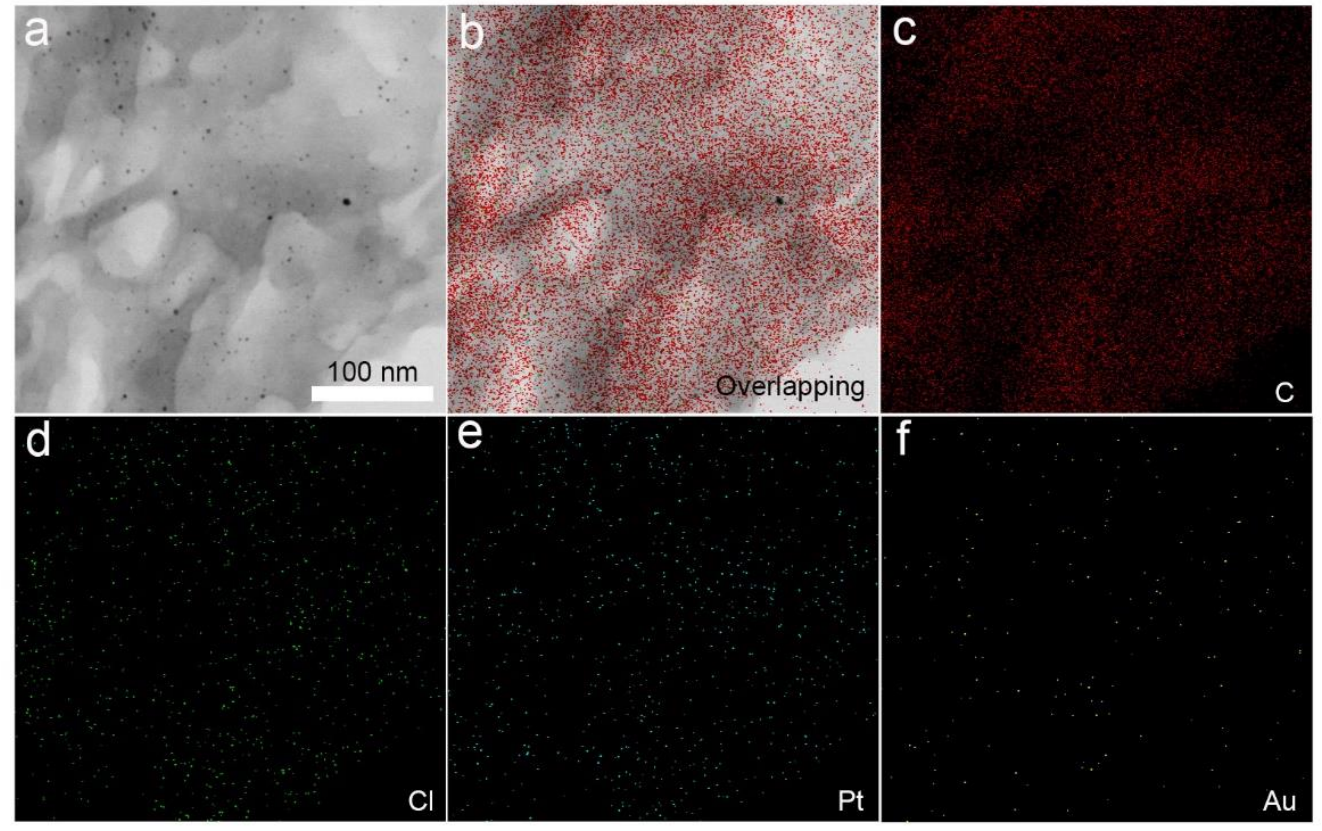

Figure S14. The (a) TEM images and (b-f) EDS mappings of the $\mathrm{PtCl}_{2} \mathrm{Au}(111) / \mathrm{GDY}$ after MOR measurements in $1.0 \mathrm{M} \mathrm{KOH}+1.0 \mathrm{M} \mathrm{CH}_{3} \mathrm{OH}$. 


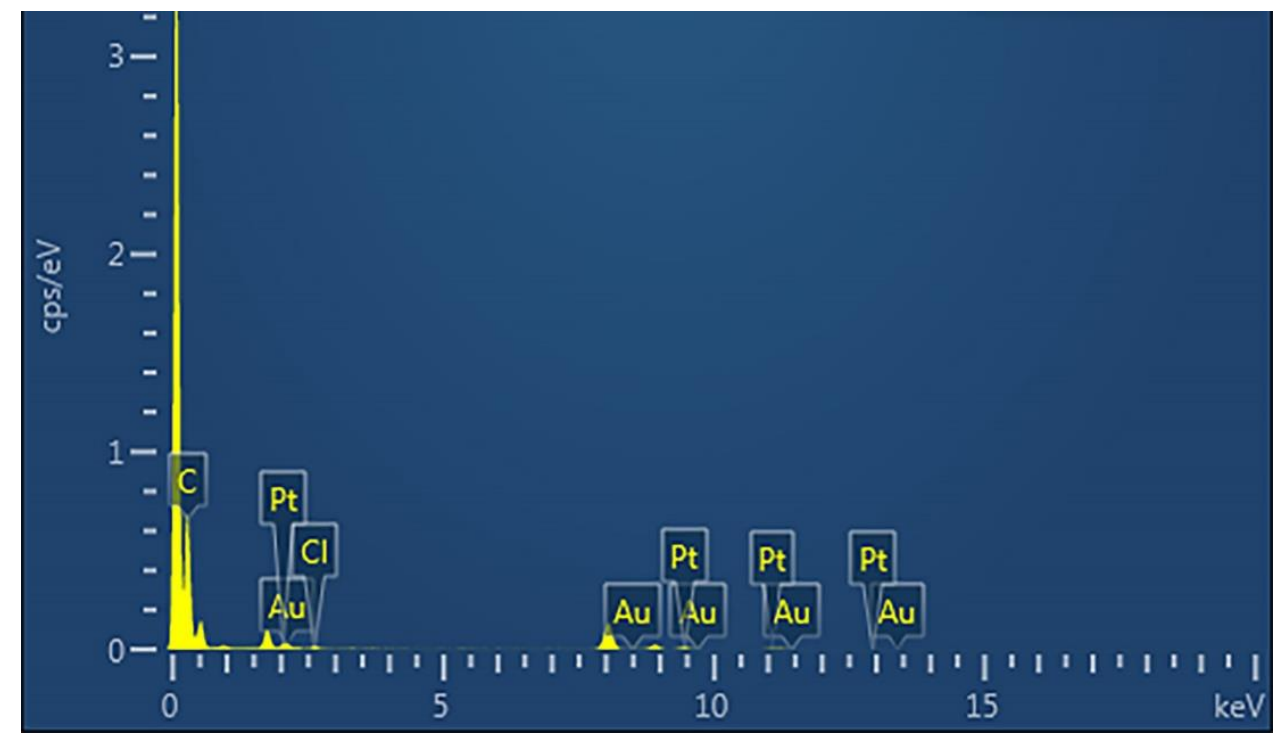

Figure S15. The EDX of the $\mathrm{PtCl}_{2} \mathrm{Au}(111) / \mathrm{GDY}$ after MOR measurements in $1.0 \mathrm{M}$ $\mathrm{KOH}+1.0 \mathrm{M} \mathrm{CH}_{3} \mathrm{OH}$. 

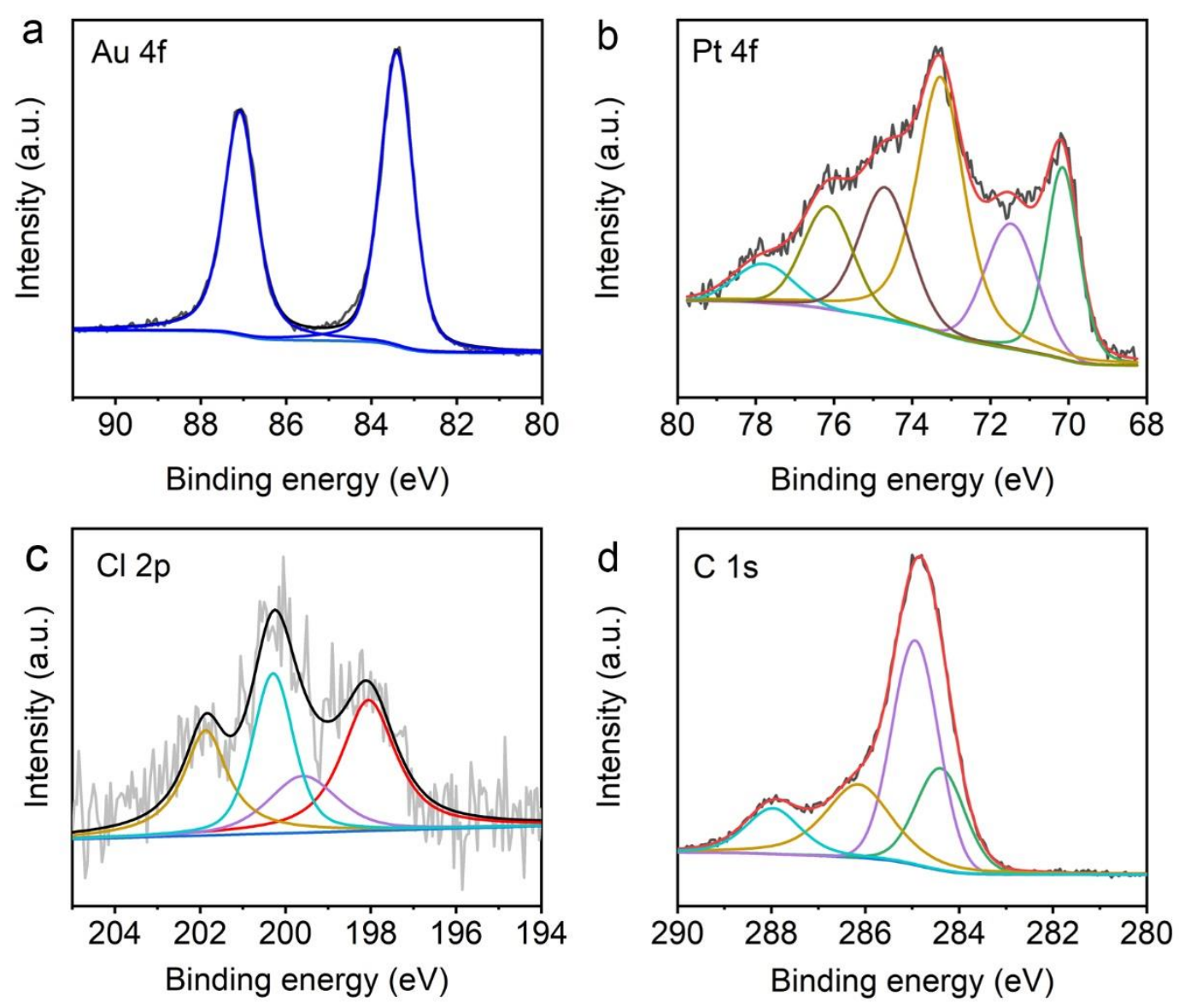

Figure S16. The (a) Au 4f, (b) Pt 4f, (c) $\mathrm{Cl} 2 \mathrm{p}$ and (d) C 1s XPS spectra of the $\mathrm{PtCl}_{2} \mathrm{Au}(111) / \mathrm{GDY}$ after i-t measurements in $1.0 \mathrm{M} \mathrm{KOH}+1.0 \mathrm{M} \mathrm{CH}_{3} \mathrm{OH}$. 

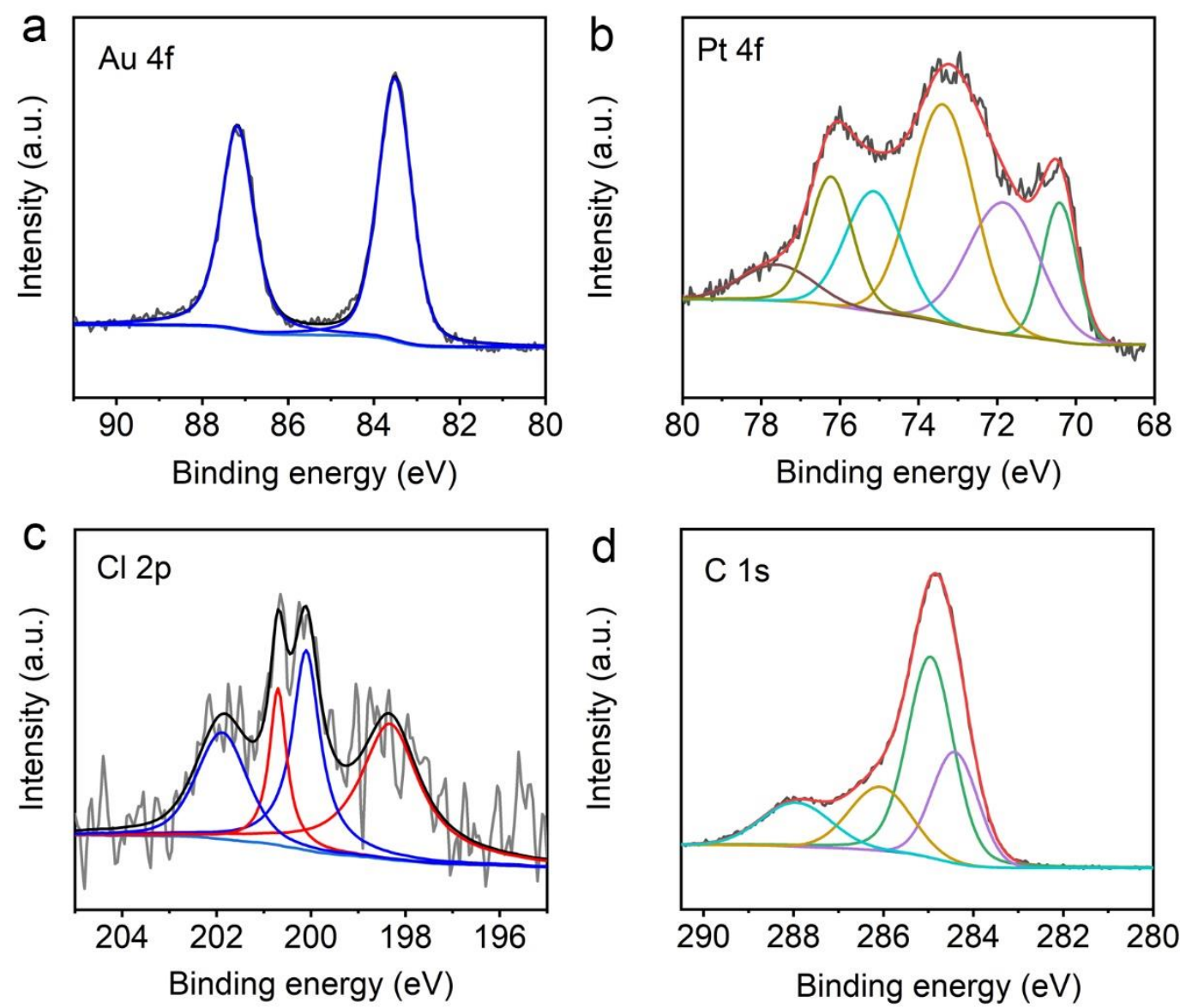

Figure S17. The (a) Au 4f, (b) Pt 4f, (c) $\mathrm{Cl} 2 \mathrm{p}$ and (d) $\mathrm{C} 1 \mathrm{~s}$ XPS spectra of the $\mathrm{PtCl}_{2} \mathrm{Au}(111) / \mathrm{GDY}$ after $\mathrm{CV}$ measurements in $1.0 \mathrm{M} \mathrm{KOH}+1.0 \mathrm{M} \mathrm{CH}_{3} \mathrm{OH}$. 


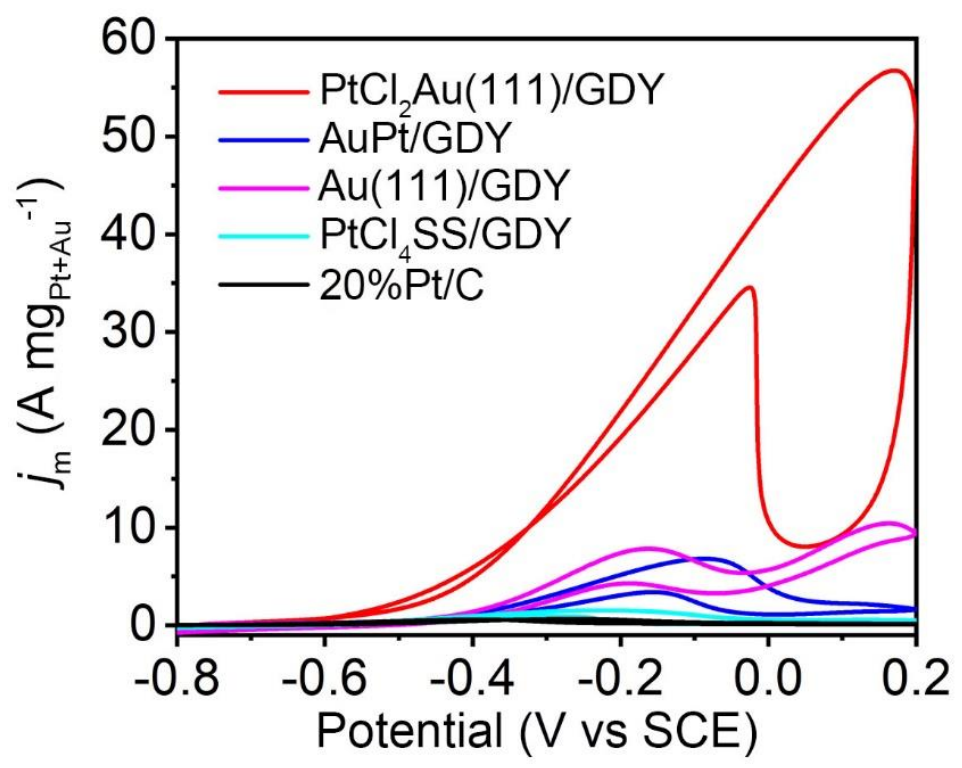

Figure S18. All metal $(\mathrm{Pt}+\mathrm{Au})$ mass-normalized $\mathrm{CV}$ curves of different samples for EOR. 

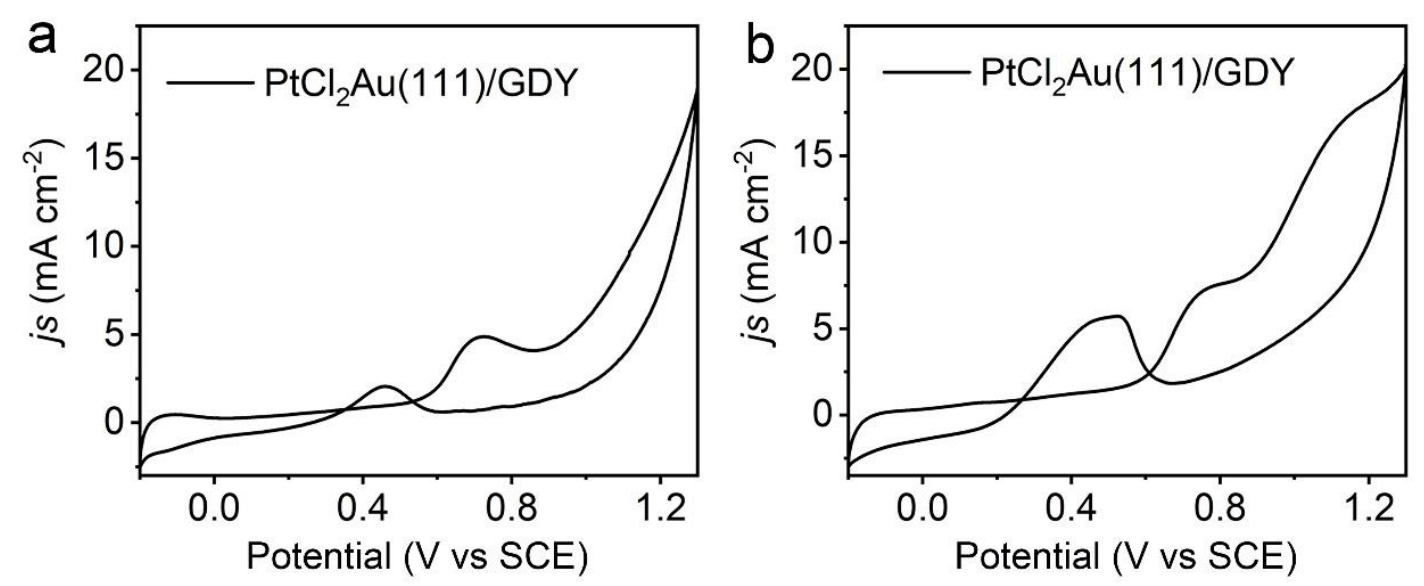

Figure S19. The CV curves of $\mathrm{PtCl}_{2} \mathrm{Au}(111) / \mathrm{GDY}$ obtained in (a) $0.5 \mathrm{M} \mathrm{H}_{2} \mathrm{SO}_{4}+1.0$ $\mathrm{M} \mathrm{CH}_{3} \mathrm{OH}$ for MOR and (b) $0.5 \mathrm{M} \mathrm{H}_{2} \mathrm{SO}_{4}+1.0 \mathrm{M} \mathrm{CH}_{3} \mathrm{CH}_{2} \mathrm{OH}$ for EOR, respectively. We studied the MOR and EOR performances of the $\mathrm{PtCl}_{2} \mathrm{Au}(111) / \mathrm{GDY}$ in $0.5 \mathrm{M} \mathrm{H}_{2} \mathrm{SO}_{4}$ containing 1.0 M methanol ( or 1.0 M ethanol) at $50 \mathrm{mV} \mathrm{s}^{-1}$. As shown in Figures S19a and 19b, the specific activities of $\mathrm{PtCl}_{2} \mathrm{Au}(111) / \mathrm{GDY}$ were calculated to be $5.0 \mathrm{~mA}$ $\mathrm{cm}^{-2}$ for MOR and $5.1 \mathrm{~mA} \mathrm{~cm}{ }^{-2}$ for EOR, respectively. These values are higher than previously reported MOR catalysts, such as PtRu NWs $\left(1.16 \mathrm{~mA} \mathrm{~cm}^{-2}, J\right.$. Am. Chem. Soc. 2018, 140, 1142-1147.), AL-Pt/Pt ${ }_{3} \mathrm{Ga}\left(1.04 \mathrm{~mA} \mathrm{~cm}{ }^{-2}, J\right.$. Am. Chem. Soc. 2018, 140, 2773-2776.) and PtNi CNCs (1.37 mA cm${ }^{-2}$, Adv. Funct. Mater. 2018, 28, 1704774.). These results confirmed the excellent performances of $\mathrm{PtCl}_{2} \mathrm{Au}(111) / \mathrm{GDY}$ in both alkaline and acidic conditions. 


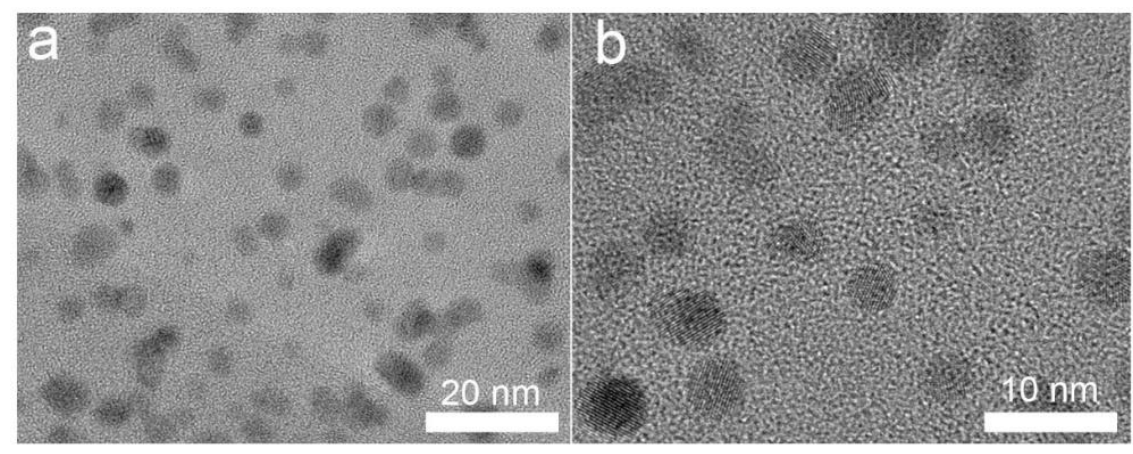

Figure S20. (a, b) The TEM images of the $\mathrm{PtCl}_{2} \mathrm{Au}(111) / \mathrm{GDY}$ after EOR measurements in $1.0 \mathrm{M} \mathrm{KOH}+1.0 \mathrm{M} \mathrm{CH}_{3} \mathrm{CH}_{2} \mathrm{OH}$. 


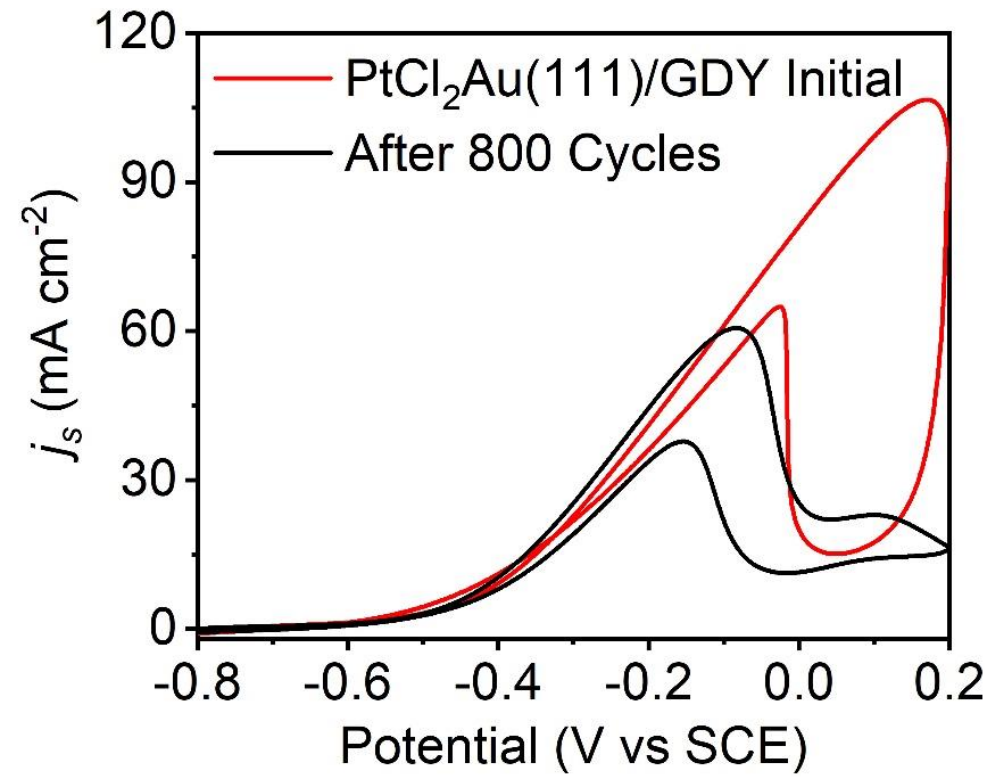

Figure S21. The CV curves of $\mathrm{PtCl}_{2} \mathrm{Au}(111) / \mathrm{GDY}$ in $1.0 \mathrm{M} \mathrm{KOH}+1.0 \mathrm{M} \mathrm{CH}_{3} \mathrm{OH}$ for EOR before and after 800 cycles. 

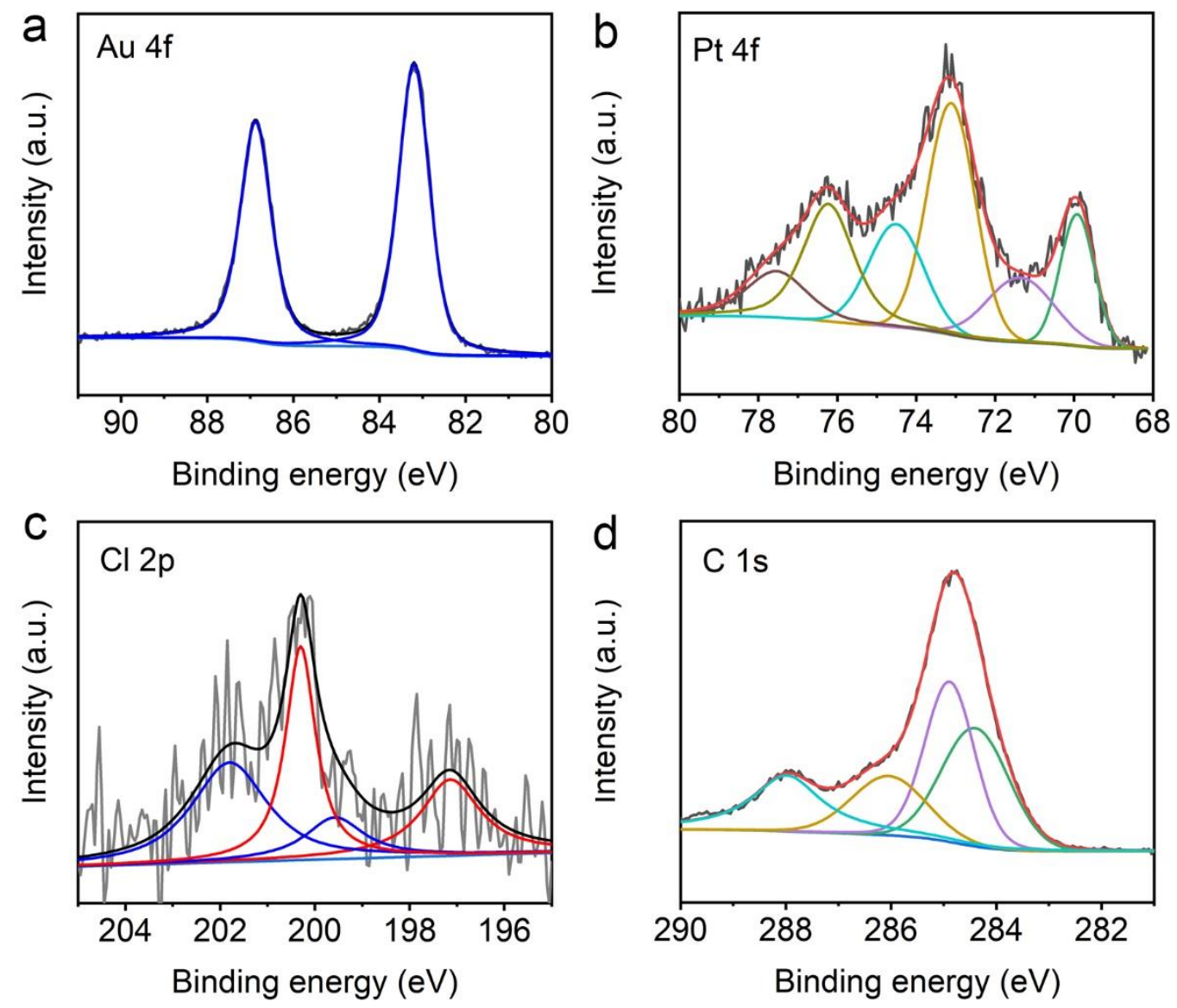

Figure S22. The (a) Au 4f, (b) Pt 4f, (c) $\mathrm{Cl} 2 \mathrm{p}$ and (d) C 1s XPS spectra of the $\mathrm{PtCl}_{2} \mathrm{Au}(111) / \mathrm{GDY}$ after i-t measurements in $1.0 \mathrm{M} \mathrm{KOH}+1.0 \mathrm{M} \mathrm{CH}_{3} \mathrm{CH}_{2} \mathrm{OH}$. 

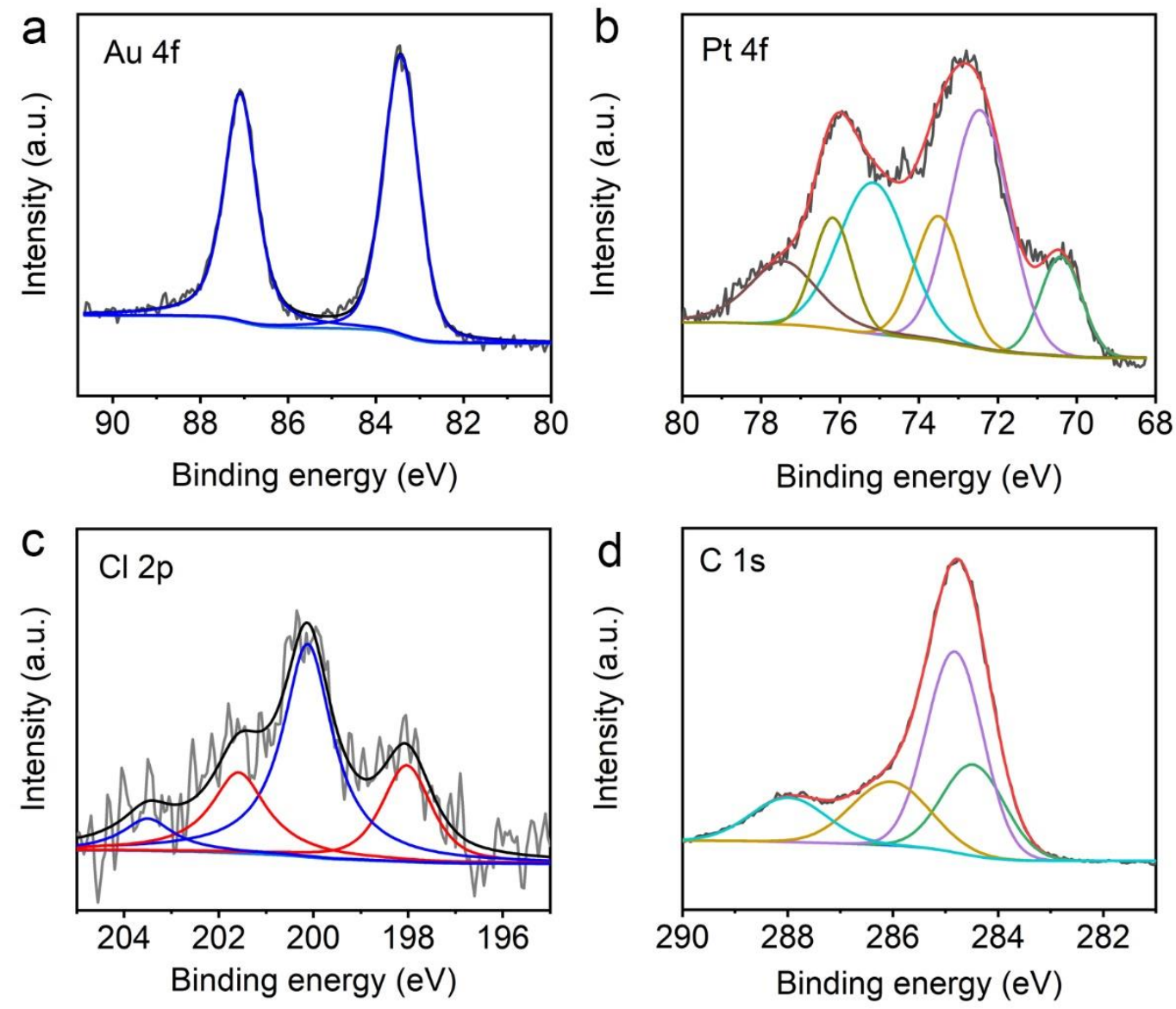

Figure S23. The (a) Au 4f, (b) Pt 4f, (c) $\mathrm{Cl} 2 \mathrm{p}$ and (d) C 1s XPS spectra of the $\mathrm{PtCl}_{2} \mathrm{Au}(111) / \mathrm{GDY}$ after $\mathrm{CV}$ measurements in $1.0 \mathrm{M} \mathrm{KOH}+1.0 \mathrm{M} \mathrm{CH}_{3} \mathrm{CH}_{2} \mathrm{OH}$. 

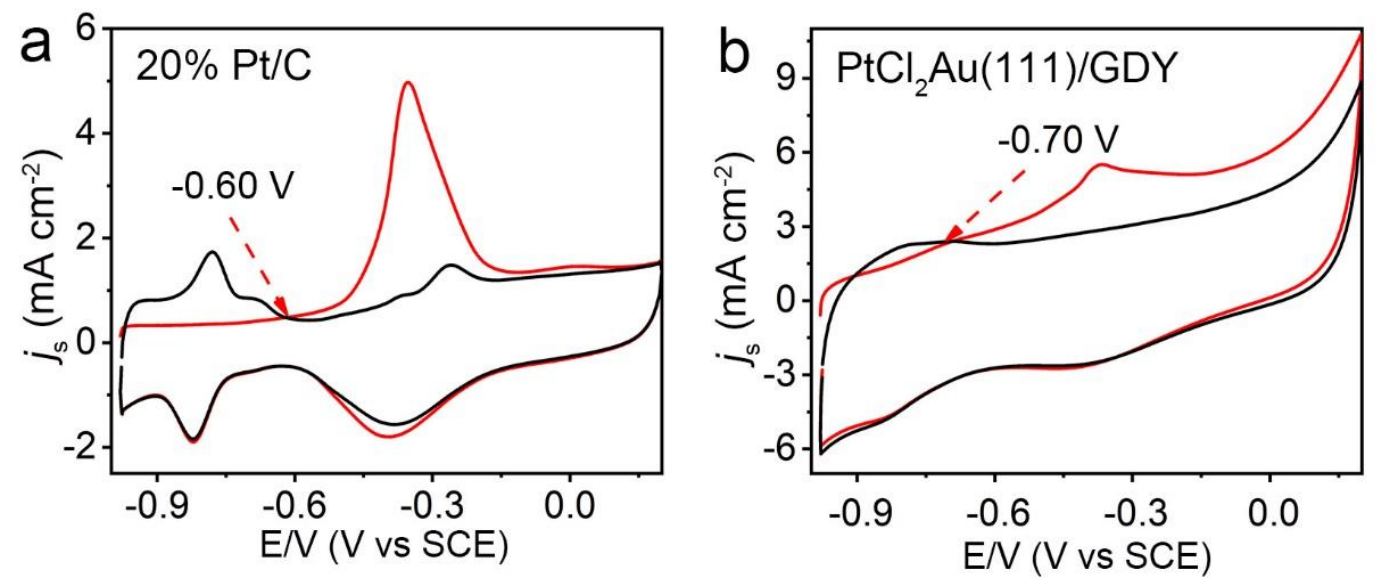

Figure S24. The $\mathrm{CO}$ stripping measurements of (a) the $20 \% \mathrm{Pt} / \mathrm{C}$ and (b) $\mathrm{PtCl}_{2} \mathrm{Au}(111) / \mathrm{GDY}$ in $1.0 \mathrm{M} \mathrm{KOH}$. 


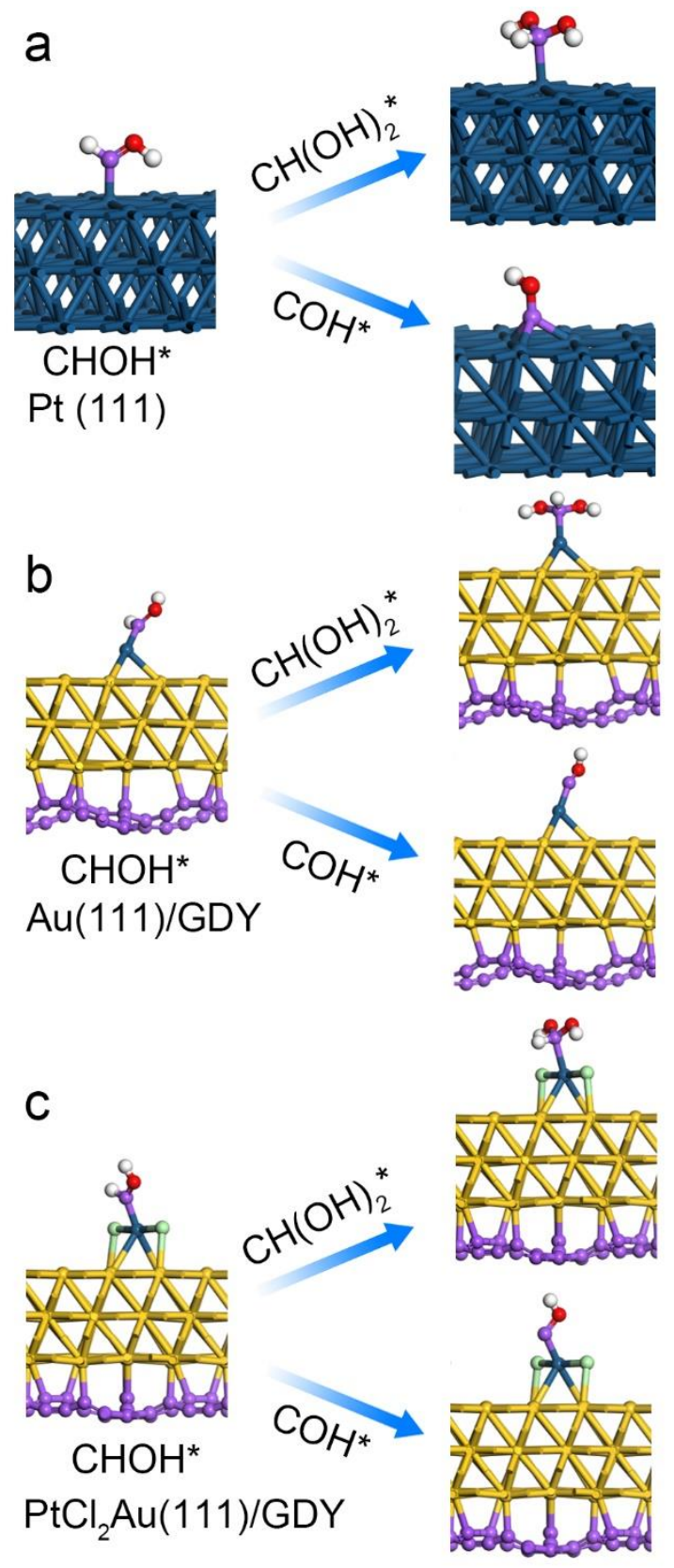

Figure S25. The DFT models of the Pt (111), $\mathrm{Au}(111) / \mathrm{GDY}$ and $\mathrm{PtCl}_{2} \mathrm{Au}(111) / \mathrm{GDY}$. 


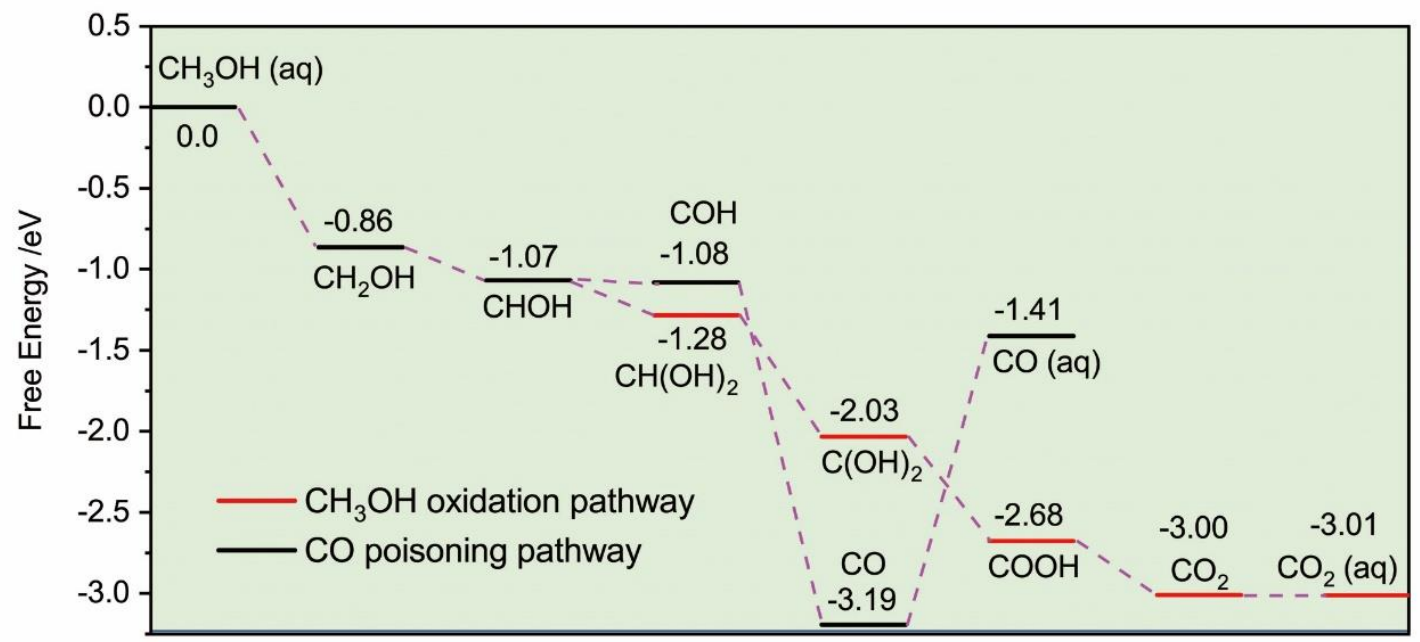

Figure S26. The energetic pathway for MOR and CO poisoning on the PtAu(111)/GDY. A continuum solvent model with dielectric constant 78.4 was used, together with a limiting potential of only $0.48 \mathrm{~V}$ vs. RHE. 


\section{Supplementary Tables}

Table S1. The mass fraction for $\mathrm{Pt}, \mathrm{Au}$ and $\mathrm{Cl}$ elements in the catalyst determined by HAADF-STEM-EDS.

\begin{tabular}{|c|c|c|}
\hline Element & Family & Mass Fraction (\%) \\
\hline $\mathrm{Pt}$ & $\mathrm{L}$ & 0.16 \\
\hline $\mathrm{Au}$ & $\mathrm{L}$ & 5.52 \\
\hline $\mathrm{Cl}$ & $\mathrm{K}$ & 0.91 \\
\hline $\mathrm{C}$ & $\mathrm{K}$ & 93.41 \\
\hline
\end{tabular}


Table S2. EXAFS fitting parameters at the Au L3-edge for various samples.

\begin{tabular}{|c|c|c|c|c|c|c|}
\hline Samples & Shell & $\mathbf{N}^{\mathbf{a}}$ & $\mathbf{R}(\mathbf{\AA})^{\mathbf{b}}$ & $\boldsymbol{\sigma}^{\mathbf{2}}\left(\mathbf{\AA}^{\left.\mathbf{2} \cdot \mathbf{1 0}^{-3}\right)} \mathbf{c}\right.$ & $\begin{array}{c}\Delta \mathbf{E} \mathbf{0} \\
(\mathbf{e V})\end{array}$ & $\begin{array}{c}\boldsymbol{R} \text { factor } \\
(\mathbf{\%})\end{array}$ \\
\hline $\mathrm{PtCl}_{2} \mathrm{Au}(111) / \mathrm{GDY}$ & $\mathrm{Au}-\mathrm{Au}$ & 11.7 & 2.85 & 8.3 & 4.8 & 0.9 \\
\hline $\mathrm{Au}(111) / \mathrm{GDY}$ & $\mathrm{Au}-\mathrm{Au}$ & 10.6 & 2.86 & 7.6 & 4.8 & 0.4 \\
\hline
\end{tabular}

${ }^{a} N$ : coordination numbers; ${ }^{b} R$ : bond distance; ${ }^{c} \sigma^{2}$ : Debye-Waller factors; ${ }^{d} \Delta E_{0}$ : the inner potential correction. $R$ factor: goodness of fit. $S 02$ was set as 0.823 for $\mathrm{Au}-\mathrm{Au}$, which was obtained from the experimental EXAFS fit of reference Au foil by fixing $\mathrm{CN}$ as the known crystallographic value and was fixed to all the samples. 
Table S3. EXAFS fitting parameters at the Pt L3-edge for various samples.

\begin{tabular}{|c|c|c|c|c|c|c|}
\hline Sample & Shell & $\mathbf{N}^{\mathbf{a}}$ & $\mathbf{R}(\AA)^{b}$ & $\sigma^{2}\left(\AA^{2} \cdot 10^{-3}\right)^{c}$ & $\Delta E 0(e V)^{d}$ & $\begin{array}{c}R \\
\text { factor } \\
(\%)\end{array}$ \\
\hline \multirow{2}{*}{$\mathrm{PtCl}_{4} \mathrm{SS} / \mathrm{GDY}$} & $\mathrm{Pt}-\mathrm{O}$ & 0.5 & 1.81 & 13.3 & -11.0 & \multirow{2}{*}{0.2} \\
\hline & $\mathrm{Pt}-\mathrm{Cl}$ & 3.7 & 2.29 & 2.9 & 8.6 & \\
\hline
\end{tabular}

${ }^{a} N$ : coordination numbers; ${ }^{b} R$ : bond distance; ${ }^{c} \sigma^{2}$ : Debye-Waller factors; ${ }^{d} \Delta E_{0}$ : the inner potential correction. $R$ factor: goodness of fit. $S 02$ were set as $0.840 / 0.872$ for Pt-O/Pt$\mathrm{Cl}$, which were obtained from the experimental EXAFS fit of reference $\mathrm{PtO}_{2} / \mathrm{K}_{2} \mathrm{PtCl}_{4}$ by fixing $\mathrm{CN}$ as the known crystallographic value and was fixed to all the samples. 
Table S4. The inductively coupled plasma atomic emission spectroscopy of these samples.

\begin{tabular}{|c|c|c|}
\hline Samples & Pt (wt\%) & Au (wt\%) \\
\hline $\mathrm{PtCl}_{2} \mathrm{Au}(111) / \mathrm{GDY}$ & 0.13 & 0.26 \\
\hline $\mathrm{PtCl}_{4} \mathrm{SSGDY}$ & 0.21 & $/$ \\
\hline $\mathrm{Au}(111) / \mathrm{GDY}$ & $/$ & 0.45 \\
\hline
\end{tabular}

In order to further clarify the element composition in the samples, the inductively coupled plasma atomic emission spectroscopy (ICP-AES, Table S4) measurements for the samples were performed. The ICP-MS results revealed that the Pt and Au on GDY loading are $0.13 \mathrm{wt} \%$ and $0.26 \mathrm{wt} \%$, respectively (Table S4). There is a difference between ICP-AES and EDS results. These results are difference between ICP-AES and EDS. Due to the scanning electron microscopy EDS measurements only collect the information on the element composition from small local areas, the ICP-AES data were used for corresponding calculations in this manuscript. 
Table S5. Comparison of the ECSA of $\mathrm{PtCl}_{2} \mathrm{Au}(111) / \mathrm{GDY}$ with the reported electrocatalysts in alkaline electrolytes.

\begin{tabular}{|c|c|c|}
\hline Electrocatalyst & ECSA $\left[\mathbf{m}^{\mathbf{2}} \mathbf{g}^{-\mathbf{1}}\right]$ & Ref. \\
\hline $\mathrm{PtCl}{ }_{2} \mathrm{Au}(111) / \mathrm{GDY}$ & 155 & This work \\
\hline $\mathrm{SANi}-\mathrm{Pt} \mathrm{NWs}$ & $106.2 \pm 4.5$ & Nat. Catal. 2019, 2, 495-503. \\
\hline $\mathrm{Au} @ \mathrm{Pt}-\mathrm{Pd} \mathrm{H}-\mathrm{Ss}$ & 86.9 & Adv. Mater. 2021, 2100713 \\
\hline $\mathrm{Pt} / \mathrm{Ni}(\mathrm{OH})_{2} / \mathrm{rGO}$ & 64.1 & Nat. Commun. 2015, 6, 10035 \\
\hline $\mathrm{PdNi}$ & 27.5 & Adv. Mater. 2020, 32, 2000482 \\
\hline $\mathrm{Au} / \mathrm{Ag} / \mathrm{Pt}$ & 70.24 & Adv. Mater. 2015, 27, 5573 \\
\hline $\mathrm{Pd} / \mathrm{Pt}-\mathrm{FNMs}$ & 52.04 & Adv. Mater. 2012, 24, 1594 \\
\hline $\mathrm{Pd} / \mathrm{PdPt}$ & 43 & Angew. Chem. Int. Ed. 2017, 56, \\
\hline $\mathrm{PtCuNFs}$ & 12.4 & Adv. Mater. 2016, 28, 8712 \\
\hline
\end{tabular}


Table S6. The relative contents of $\mathrm{Pt}, \mathrm{Au}$ and $\mathrm{Cl}$ and the $\mathrm{Cl} / \mathrm{Pt}$ ratios of the samples before and after the long-term stability tests according to the XPS data.

\begin{tabular}{|c|c|c|c|}
\hline Samples & Pt content (\%) & Cl content (\%) & Cl/Pt Ratios \\
\hline Freshly-prepared & $29.98 \%$ & $9.52 \%$ & 0.32 \\
\hline After $\mathrm{CV}\left(\mathrm{CH}_{3} \mathrm{OH}\right)$ & $61.20 \%$ & $6.62 \%$ & 0.11 \\
\hline After i-t $\left(\mathrm{CH}_{3} \mathrm{OH}\right)$ & $62.63 \%$ & $5.64 \%$ & 0.09 \\
\hline After $\mathrm{CV}\left(\mathrm{CH}_{3} \mathrm{CH}_{2} \mathrm{OH}\right)$ & $64.04 \%$ & $4.74 \%$ & 0.07 \\
\hline After i-t $\left(\mathrm{CH}_{3} \mathrm{CH}_{2} \mathrm{OH}\right)$ & $62.63 \%$ & $6.25 \%$ & 0.1 \\
\hline
\end{tabular}

The XPS was used to determine the changes of the $\mathrm{Pt}$ and $\mathrm{Cl}$ species in the catalyst before and after long-term stability tests. The proportion of $\mathrm{Pt}$ and $\mathrm{Cl}$ species for the samples before and after long-term stability tests were calculated and illustrated in Table S6. For freshly-prepared $\mathrm{PtCl}_{2} \mathrm{Au}(111) / \mathrm{GDY}$, the contents of $\mathrm{Pt}$ and $\mathrm{Cl}$ species were determined to be $29.98 \%$ and $9.52 \%$, respectively, and the $\mathrm{Cl} / \mathrm{Pt}$ ratio was calculated to be 0.32 . After the long-term stability tests (i-t and CV cycling tests) both in $1.0 \mathrm{M} \mathrm{KOH}+1.0 \mathrm{M} \mathrm{CH}_{3} \mathrm{OH}(\mathrm{MOR})$ and $1.0 \mathrm{M} \mathrm{KOH}+1.0 \mathrm{M} \mathrm{CH}_{3} \mathrm{CH}_{2} \mathrm{OH}$ (EOR) conditions, the relative contents of $\mathrm{Pt}$ and $\mathrm{Cl}$ species and the $\mathrm{Cl} / \mathrm{Pt}$ ratios all exhibited obvious decreases, which demonstrate the loss of $\mathrm{Cl}$ during the long-term stability tests. Based on the above discussion, we can safely conclude that the $\mathrm{Cl}$ species play a key role in maintaining the catalytic performances of the catalyst during the MOR and EOR processes. 
Table S7. Comparison of the MOR performances of $\mathrm{PtCl}_{2} \mathrm{Au}(111) / \mathrm{GDY}$ with reported electrocatalysts in $1 \mathrm{M} \mathrm{KOH}$ electrolytes available from literatures.

\begin{tabular}{|c|c|c|c|}
\hline Electrocatalyst & Electrolyte & $\begin{array}{c}\text { Peak current from } \\
\text { CV curves }\end{array}$ & Reference \\
\hline $\mathrm{PtCl}_{2} \mathrm{Au}(111) / \mathrm{GDY}$ & $\begin{array}{l}1.0 \mathrm{M} \mathrm{KOH} \mathrm{+} \\
1.0 \mathrm{M} \text { methanol }\end{array}$ & $\begin{array}{c}175.64 \mathrm{~A} \mathrm{mg} \mathrm{Pt}^{-1} \\
\left(j_{s}=113.2 \mathrm{~mA} \mathrm{~cm}^{-2}\right) \\
\left(60.25 \mathrm{~A} \mathrm{mg}_{\mathrm{Pt}^{-} \mathrm{Au}}{ }^{-1}\right)\end{array}$ & This work \\
\hline $\mathrm{Pt}_{1} / \mathrm{RuO}_{2}$ & $\begin{array}{l}1.0 \mathrm{M} \mathrm{KOH} \mathrm{+} \\
1.0 \mathrm{M} \text { ethanol }\end{array}$ & $6.77 \mathrm{~A} \mathrm{mg}_{\mathrm{Pt}}^{-1}$ & $\begin{array}{l}\text { Nat. Commun. } \\
\text { 2021, } 12,5235\end{array}$ \\
\hline SANi-Pt NWs & $\begin{array}{l}1.0 \mathrm{M} \mathrm{KOH} \mathrm{+} \\
1.0 \mathrm{M} \text { ethanol }\end{array}$ & $7.93 \mathrm{~A} \mathrm{mg} \mathrm{Pt}^{-1}$ & $\begin{array}{c}\text { Nat. Catal. 2019, } \\
\text { 2, 495-503. }\end{array}$ \\
\hline $\begin{array}{c}\mathrm{Pt}_{18} \mathrm{Ni}_{26} \mathrm{Fe}_{15} \mathrm{Co}_{14} \mathrm{Cu}_{2} \\
{ }_{7} / \mathrm{C} \\
\end{array}$ & $\begin{array}{l}1.0 \mathrm{M} \mathrm{KOH} \mathrm{+} \\
1.0 \mathrm{M} \text { ethanol } \\
\end{array}$ & 15.04 $\mathrm{A} \mathrm{mg} \mathrm{Pt}^{-1}$ & $\begin{array}{l}\text { Nat. Commun. } \\
\text { 2020, } 11,5437\end{array}$ \\
\hline o-PdH0.43@Pt NPs & $\begin{array}{l}1.0 \mathrm{M} \mathrm{KOH} \mathrm{+} \\
1.0 \mathrm{M} \text { ethanol }\end{array}$ & $\begin{array}{c}3.68 \mathrm{~A} \mathrm{mg}^{-1} \\
\left(32.51 \mathrm{~A} \mathrm{mgPt}^{-1}\right)\end{array}$ & $\begin{array}{c}\text { J. Am. Chem. Soc. } \\
\text { 2021, 143,11262- } \\
11270 .\end{array}$ \\
\hline $\begin{array}{c}\mathrm{Au} @ \\
\mathrm{Pt}_{1}-\mathrm{Pd}_{1} \mathrm{H}-\mathrm{Ss}\end{array}$ & $\begin{array}{l}1.0 \mathrm{M} \mathrm{KOH} \mathrm{+} \\
1.0 \mathrm{M} \text { ethanol }\end{array}$ & $\begin{array}{l}4.38{\mathrm{~A} \mathrm{mg} \mathrm{Pt}+\mathrm{pd}^{-1}}_{\left(5.04 \mathrm{~mA} \mathrm{~cm}^{-2}\right)}\end{array}$ & $\begin{array}{c}\text { Adv. Mater. 2021, } \\
\text { 33, } 2100713\end{array}$ \\
\hline PtNiNF-NGA & $\begin{array}{l}1.0 \mathrm{M} \mathrm{KOH} \mathrm{+} \\
1.0 \mathrm{M} \text { ethanol }\end{array}$ & $\begin{array}{l}1.65 \mathrm{~A} \mathrm{mg} \mathrm{Pt}^{-1} \\
\left(3.8 \mathrm{~mA} \mathrm{~cm}^{-2}\right)\end{array}$ & $\begin{array}{c}\text { Angew. Chem. Int } \\
\text { Ed. 2021, 60, } \\
9590-9597\end{array}$ \\
\hline $\mathrm{PtCu}$ & $\begin{array}{c}0.5 \mathrm{M} \mathrm{KOH}+ \\
1.0 \mathrm{M} \text { methanol }\end{array}$ & $\begin{array}{c}2.26 \mathrm{~A} \mathrm{mg} \mathrm{Pt}^{-1} \\
\left(18.20 \mathrm{~mA} \mathrm{~cm}^{-2}\right)\end{array}$ & $\begin{array}{c}\text { Adv. Mater. 2016, } \\
\text { 28, 8712-8717 }\end{array}$ \\
\hline $\mathrm{Pt} / \mathrm{Ni}(\mathrm{OH})_{2} / \mathrm{rGO}$ & $\begin{array}{l}1.0 \mathrm{M} \mathrm{KOH} \mathrm{+} \\
1.0 \mathrm{M} \text { ethanol }\end{array}$ & $1.24 \mathrm{~A} \mathrm{mg} \mathrm{Pt}^{-1}$ & $\begin{array}{l}\text { Nat. Commun. } \\
\text { 2015, 6, } 10035\end{array}$ \\
\hline
\end{tabular}


Table S8. Comparison the EOR performances of $\mathrm{PtCl}_{2} \mathrm{Au}(111)$ /GDY electrocatalysts in $1 \mathrm{M} \mathrm{KOH}$ electrolytes available from literatures.

\begin{tabular}{|c|c|c|c|}
\hline Catalysts & Electrolyte & Mass activity & Reference \\
\hline $\mathrm{PtCl}_{2} \mathrm{Au}(111) / \mathrm{GDY}$ & $\begin{array}{l}1.0 \mathrm{M} \mathrm{KOH} \mathrm{+} \\
1.0 \mathrm{M} \text { ethanol }\end{array}$ & $\begin{array}{c}165.35 \mathrm{~A} \mathrm{mg}_{\mathrm{Pt}}^{-1} \\
\left(j_{s}=101.75 \mathrm{~mA} \mathrm{~cm}^{-2}\right) \\
\left(56.75 \mathrm{~A} \mathrm{mgPt}^{-1}\right)\end{array}$ & This work \\
\hline PdZn/NC@ZnO & $\begin{array}{l}1.0 \mathrm{M} \mathrm{KOH} \mathrm{+} \\
1.0 \mathrm{M} \text { ethanol }\end{array}$ & $\begin{array}{l}18.14 \mathrm{~A} \mathrm{mg}_{\mathrm{Pd}}{ }^{-1} \\
\left(54.60 \mathrm{~A} \mathrm{~cm}^{-2}\right)\end{array}$ & $\begin{array}{l}\text { Nat. Commun. } \\
\mathbf{2 0 2 1}, 12,5273 .\end{array}$ \\
\hline $\boldsymbol{o}-\mathrm{PdH}_{0.43} @ \mathrm{Pt}$ & $\begin{array}{l}1.0 \mathrm{M} \mathrm{KOH} \mathrm{+} \\
1.0 \mathrm{M} \text { ethanol }\end{array}$ & $\begin{array}{l}1.68 \mathrm{~A} \mathrm{mg}_{\mathrm{Pd}+\mathrm{Pt}}{ }^{-1} \\
\left(14.68 \mathrm{~A} \mathrm{mg}_{\mathrm{Pt}}^{-1}\right)\end{array}$ & $\begin{array}{c}\text { J. Am. Chem. Soc. } \\
\text { 2021, 143,11262- } \\
11270 .\end{array}$ \\
\hline $\begin{array}{c}\mathrm{Au} @ \\
\mathrm{Pt}_{1}-\mathrm{Pd}_{1} \mathrm{H}-\mathrm{Ss}\end{array}$ & $\begin{array}{l}1.0 \mathrm{M} \mathrm{KOH} \mathrm{+} \\
1.0 \mathrm{M} \text { ethanol }\end{array}$ & $3.18 \mathrm{~A} \mathrm{mg}_{\mathrm{Pt}+\mathrm{Pd}}^{-1}$ & $\begin{array}{c}\text { Adv. Mater. 2021, } \\
\text { 33, } 2100713\end{array}$ \\
\hline SANi-Pt NWs & $\begin{array}{l}1.0 \mathrm{M} \mathrm{KOH} \mathrm{+} \\
1.0 \mathrm{M} \text { ethanol } \\
\end{array}$ & $5.60 \mathrm{~A} \mathrm{mg}_{\mathrm{Pt}}^{-1}$ & $\begin{array}{c}\text { Nat. Catal. 2019, } \\
\text { 2, 495-503. }\end{array}$ \\
\hline $\mathrm{Au}_{10} @ \mathrm{Pt}_{1} \mathrm{Ir}_{0.7}$ & $\begin{array}{l}1.0 \mathrm{M} \mathrm{KOH} \mathrm{+} \\
1.0 \mathrm{M} \text { ethanol }\end{array}$ & $8.3 \mathrm{~A} \mathrm{mg}_{\mathrm{Pt}}^{-1}$ & $\begin{array}{c}\text { J. Am. Chem. Soc. } \\
\text { 2019, } 141,9629- \\
9636 .\end{array}$ \\
\hline $\begin{array}{c}\mathrm{PdAg} \\
\text { nanodendrites }\end{array}$ & $\begin{array}{l}1.0 \mathrm{M} \mathrm{KOH} \mathrm{+} \\
1.0 \mathrm{M} \text { ethanol }\end{array}$ & $2.63 \mathrm{~A} \mathrm{mg}_{\mathrm{Pt}}^{-1}$ & $\begin{array}{c}\text { Adv. Mater. 2018, } \\
30,1706962\end{array}$ \\
\hline Octahedral PtRhNi & $\begin{array}{l}1.0 \mathrm{M} \mathrm{KOH} \mathrm{+} \\
1.0 \mathrm{M} \text { ethanol }\end{array}$ & $1.40 \mathrm{~A} \mathrm{mgPt}^{-1}$ & $\begin{array}{c}\text { Angew. Chem. Int. } \\
\text { Ed. 2017, 56, } \\
\text { 6533-6538 }\end{array}$ \\
\hline 4H/fcc Au@Pd & $\begin{array}{l}1.0 \mathrm{M} \mathrm{KOH} \mathrm{+} \\
1.0 \mathrm{M} \text { ethanol }\end{array}$ & $2.92 \mathrm{~A} \mathrm{mg}_{\mathrm{Pt}}^{-1}$ & $\begin{array}{c}\text { Adv. Mater. 2017, } \\
\text { 29, } 1701331\end{array}$ \\
\hline $\mathrm{Pd}_{40} \mathrm{Ni}_{34} \mathrm{P}_{17} \mathrm{NP} / \mathrm{C}$ & $\begin{array}{l}1.0 \mathrm{M} \mathrm{KOH} \mathrm{+} \\
1.0 \mathrm{M} \text { ethanol }\end{array}$ & $4.95 \mathrm{~A} \mathrm{mg}_{\mathrm{Pt}}^{-1}$ & $\begin{array}{l}\text { Nat. Commun. } \\
\mathbf{2 0 1 7}, 8,14136 .\end{array}$ \\
\hline $\mathrm{Pd} / \mathrm{Ni}(\mathrm{OH})_{2} / \mathrm{rGO}$ & $\begin{array}{l}1.0 \mathrm{M} \mathrm{KOH} \mathrm{+} \\
1.0 \mathrm{M} \text { ethanol }\end{array}$ & $1.55 \mathrm{~A} \mathrm{mg}_{\mathrm{Pt}}^{-1}$ & $\begin{array}{c}\text { Adv. Mater. } \mathbf{2 0 1 7}, \\
\text { 29, } 1703057 .\end{array}$ \\
\hline PdPtAg NSs & $\begin{array}{l}0.1 \mathrm{M} \mathrm{KOH}+ \\
0.5 \mathrm{M} \text { ethanol }\end{array}$ & $1.33 \mathrm{~A} \mathrm{mg}_{\mathrm{Pt}}^{-1}$ & $\begin{array}{c}\text { Angew. Chem. Int. } \\
\text { Ed. 2016, 55, } \\
\text { 2753-2758 }\end{array}$ \\
\hline $\mathrm{PdCo} / \mathrm{CC}$ & $\begin{array}{l}1.0 \mathrm{M} \mathrm{KOH} \mathrm{+} \\
1.0 \mathrm{M} \text { ethanol }\end{array}$ & $1.50 \mathrm{~A} \mathrm{mg}_{\mathrm{Pt}}^{-1}$ & $\begin{array}{c}\text { Angew. Chem. Int. } \\
\text { Ed. 2015, 54, } \\
\text { 3669-3673. }\end{array}$ \\
\hline Pd aerogel & $\begin{array}{l}1.0 \mathrm{M} \mathrm{KOH} \mathrm{+} \\
1.0 \mathrm{M} \text { ethanol }\end{array}$ & $7.83 \mathrm{~A} \mathrm{mgPt}^{-1}$ & $\begin{array}{c}\text { Angew. Chem. Int. } \\
\text { Ed. 2012, 51, } \\
\text { 5743-5747 }\end{array}$ \\
\hline
\end{tabular}




\section{References}

(1) Li, G.; Li, Y.; Liu, H.; Guo, Y.; Li, Y.; Zhu, D., Architecture of graphdiyne nanoscale films. Chem. Commun. 2010, 46, 3256-3258.

(2) Ravel, B. \& Newville, M. ATHENA, ARTEMIS, HEPHAESTUS: data analysis for X-ray absorption spectroscopy using IFEFFIT. J. Synchrotron Radiat. 2005, 12, 537-541.

(3) Koningsberger, D. C. \& Prins, R. X-ray absorption: principles, applications, techniques of EXAFS, SEXAFS, and XANES (eds Koningsberger, D. C. \& Prins, R.) Wiley. 1988, 92.673.

(4) Rehr, J. J. \& Albers, R. C. Theoretical approaches to X-ray absorption fine structure. Rev. Mod. Phys. 2000, 72, 621-654.

(5) Kresse, G.; Hafner, J., Ab initio molecular dynamics for liquid metals. Phys. Rev. B 1993, $47,558-561$.

(6) Kresse, G.; Hafner, J., Ab initio molecular-dynamics simulation of the liquid-metalamorphous-semiconductor transition in germanium. Phys. Rev. B. 1994, 49, $14251-14269$.

(7) Kresse, G.; Furthmüller, J., Efficiency of ab-initio total energy calculations for metals and semiconductors using a plane-wave basis set. Comp. Mater. Sci. 1996, 6, 15-50.

(8) Kresse, G.; Furthmüller, J., Efficient iterative schemes for ab initio total-energy calculations using a plane-wave basis set. Phys. Rev. B. 1996, 54, 11169-11186.

(9) Kresse, G.; Joubert, D., From ultrasoft pseudopotentials to the projector augmentedwave method. Phys. Rev. B. 1999, 59, 1758-1775.

(10) Perdew, J. P.; Burke, K.; Ernzerhof, M., Generalized gradient approximation made simple. Phys. Rev. Lett. 1996, 77, 3865-3868.

(11) Blöchl, P. E., Projector augmented-wave method. Phys. Rev. B. 1994, 50, $17953-17979$.

(12) Monkhorst, H. J.; Pack, J. D., Special points for brillouin-zone integrations. Phys. Rev. B. 1976, 13, 5188-5192. 
(13) J. K. Norskov, T. Bligaard, A. Logadottir, J. R. Kitchin, J. G. Chen, S. Pandelov and U. Stimming, Plos One. 2005, 5, e12154-e12154.

(14) Yu, L.; Pan, X.; Cao, X.; Hu, P.; Bao, X. Oxygen reduction reaction mechanism on nitrogen-doped graphene: A density functional theory study. J. Catal. 2011, 282, $183-190$.

(15) Kattel, S.; Atanassov, P.; Kiefer, B. Density functional theory study of $\mathrm{Ni}-\mathrm{N}_{\mathrm{x}} / \mathrm{C}$ electrocatalyst for oxygen reduction in alkaline and acidic media. J. Chem. Phys. C. 2012, 116, 17378-17383.

(16) J. K. Nørskov, J. Rossmeisl, A. Logadottir, L. Lindqvist, J. R. Kitchin, T. Bligaard and H. Jónsson, Origin of the overpotential for oxygen reduction at a fuel-cell cathode. J. Chem. Phys. B. 2004, 108, 17886-17892.

(17) L. I. Bendavid and E. A. Carter, $\mathrm{CO}_{2}$ adsorption on $\mathrm{Cu}_{2} \mathrm{O}(111)$ : A DFT+U and DFT-D study. J. Chem. Phys. C. 2013, 117, 26048-26059. 